\title{
Integrated Approach for Carbon Sequestration and Wastewater Treatment Using Algal-Bacterial Consortia: Opportunities and Challenges
}

\author{
Shashirekha Viswanaathan ${ }^{1, *}$, Pitchurajan Krishna Perumal ${ }^{1}$ and Seshadri Sundaram ${ }^{2}$ (D) \\ 1 Shri AMM Murugappa Chettiar Research Centre (MCRC), Taramani, Chennai 600 113, India; \\ rk.pitchu@gmail.com \\ 2 Indigenous and Frontier Technology Research Centre (IFTR), Chennai 600 062, India; seshadri@iftr.in \\ * Correspondence: shashirekhav@mcrc.murugappa.org; Tel.: +91-9789016774
}

check for

updates

Citation: Viswanaathan, S.; Perumal,

P.K.; Sundaram, S. Integrated

Approach for Carbon Sequestration and Wastewater Treatment Using

Algal-Bacterial Consortia:

Opportunities and Challenges.

Sustainability 2022, 14, 1075. https://

doi.org/10.3390/su14031075

Academic Editor: Sushanta

Kumar Saha

Received: 9 November 2021

Accepted: 29 December 2021

Published: 18 January 2022

Publisher's Note: MDPI stays neutral with regard to jurisdictional claims in published maps and institutional affiliations.

Copyright: (c) 2022 by the authors. Licensee MDPI, Basel, Switzerland. This article is an open access article distributed under the terms and conditions of the Creative Commons Attribution (CC BY) license (https:// creativecommons.org/licenses/by/ $4.0 /)$.

\begin{abstract}
Increasing concentrations of carbon dioxide $\left(\mathrm{CO}_{2}\right)$, one of the important greenhouse gases, due to combustion of fossil fuels, particularly burning coal, have become the major cause for global warming. As a consequence, many research programs on $\mathrm{CO}_{2}$ management (capture, storage, and sequestration) are being highlighted. Biological sequestration of $\mathrm{CO}_{2}$ by algae is gaining importance, as it makes use of the photosynthetic capability of these aquatic species to efficiently capture $\mathrm{CO}_{2}$ emitted from various industries and converting it into algal biomass as well as a wide range of metabolites such as polysaccharides, amino acids, fatty acids, pigments, and vitamins. In addition, their ability to thrive in rugged conditions such as seawater, contaminated lakes, and even in certain industrial wastewaters containing high organic and inorganic nutrients loads, has attracted the attention of researchers to integrate carbon capture and wastewater treatment. Algae offer a simple solution to tertiary treatments due to their nutrient removal efficiency, particularly inorganic nitrogen and phosphorus uptake. The algal-bacterial energy nexus is an important strategy capable of removing pollutants from wastewater in a synergistic manner. This review article highlights the mechanism involved in biological fixation of $\mathrm{CO}_{2}$ by microalgae, their cultivation systems, factors influencing algal cultivation in wastewater and $\mathrm{CO}_{2}$ uptake, the effect of co-cultivation of algae and bacteria in wastewater treatment systems, and challenges and opportunities.
\end{abstract}

Keywords: algae; bacterial consortia; $\mathrm{CO}_{2}$ mitigation; wastewater treatment and synergistic effect

\section{Introduction}

The Earth's average surface temperature has increased about $1.1^{\circ} \mathrm{C}$ since the late nineteenth century due to increased carbon dioxide $\left(\mathrm{CO}_{2}\right)$ emissions into the atmosphere, largely by the anthropogenic activities. Much of the warming has occurred in the past 35 years, and most since the year 2010 [1]. Statistics show that combustion of fossil fuels for generation of power contributes about one-third of total $\mathrm{CO}_{2}$ emissions [2], resulting in an increase in $\mathrm{CO}_{2}$ concentration in the atmosphere from $280 \mathrm{ppm}$ to $400 \mathrm{ppm}$ by volume, the highest $\mathrm{CO}_{2}$ level ever recorded over the last century, leading to global climate change and consequent biological extinctions [3]. Global energy-related $\mathrm{CO}_{2}$ emissions rose by $1.7 \%$, accounting for as high as $33.1 \mathrm{Gt} \mathrm{CO}_{2}$ with $\sim 65 \%$ from direct combustion of carbon [4]. The Paris Agreement dealing with greenhouse gas (GHG) emission mitigation, adaptation, and finance, signed in 2016, aims to limit global warming to close to $1.5^{\circ} \mathrm{C}$. With the current scenario, the World Meteorological Organization projects a global average temperature rise of $3-5{ }^{\circ} \mathrm{C}$ by 2100 [5]. Efforts are being made worldwide to mitigate $\mathrm{CO}_{2}$ increase, with strategies classified under three major types:

(a) Reduced use of non-renewable energy sources including fossil-fuels.

(b) Efficient use of low carbon renewable energy sources such as solar, wind, hydro, and nuclear, as well as carbon-neutral alternative energy sources such as biomass. 
(c) Adoption of post-treatment process such as carbon-capture and storage (CCS) technology.

In this regard, much research and new technologies have highlighted $\mathrm{CO}_{2}$ management via capture, storage and sequestration. CCS technology can be managed by a number of physical methods such as using membranes, different adsorbents, and cryogenic separation; geological sequestration in depleted gas and oil reservoirs; oceanographic sequestration in deep aquifers; chemical reaction-based approaches at high temperatures, including thermo-chemical, photo-chemical, bio-photochemical, electro-chemical, electrophotochemical, radio-chemical, and biochemical conversion methods; and $\mathrm{CO}_{2}$ fixation by biological methods. Among these, the biological route is gaining prominence because $\mathrm{CO}_{2}$ captured using microalgae, in particular, can be reconverted to useful chemicals, fuels, and many other valuable products [6-8]. In this review article, the importance of microalgae in $\mathrm{CO}_{2}$ sequestration, development of viable technology for their cultivation and integration with wastewater treatment facilities, factors influencing their cultivation and $\mathrm{CO}_{2}$ uptake, and prospects and challenges associated with technology development are discussed.

\section{2. $\mathrm{CO}_{2}$ Capture and Fixation by Microalgae}

Biofixation of $\mathrm{CO}_{2}$ using microalgae is a potential option for sequestration because their $\mathrm{CO}_{2}$ fixation ability through photosynthesis with solar utilization efficiency is at least 10-fold higher than that of terrestrial plants and they also have rapid growth rates and tolerance to extreme environments [9]. Microalgae are capable of sequestering $\sim 513$ tons of $\mathrm{CO}_{2}$ and converting it into 280 tons of dry biomass ha ${ }^{-1}$ year $^{-1}$ by utilizing about $10 \%$ of solar energy [10]. It is estimated that algae can fix $>65 \mathrm{Gt}^{\text {of }}$ carbon year ${ }^{-1}$, which is equivalent to the carbon output of $\sim 65,000$ numbers of $500 \mathrm{MW}$ generating plants [11]. Microalgae are considered important in $\mathrm{CO}_{2}$ sequestration programs because they have numerous additional technological advantages. Their inherent ability to tolerate high concentrations of $\mathrm{CO}_{2}$ is advantageous, and they can be utilized to capture $\mathrm{CO}_{2}$ from flue gases generated by power plants. Algal species have rapid growth, with a cell doubling time of $24 \mathrm{~h}$, and they are adaptable to changing environmental conditions. Additionally, they can be cultivated in various types of low-quality water, ranging from municipal sewage to industrial wastewaters to seawater.

A number of microalgal strains have been shown to grow abundantly utilizing $\mathrm{CO}_{2}$ and carbonates such as $\mathrm{Na}_{2} \mathrm{CO}_{3}$ and $\mathrm{NaHCO}_{3}$. They adapt themselves to increasing $\mathrm{CO}_{2}$ concentrations via compartmentation of the RuBisCO enzyme. This involves a Carbon concentration mechanism in which inorganic carbon is fixed through active transportation of $\mathrm{CO}_{2}$ and bicarbonates with RuBisCo separated by a multi-layered membrane $[12,13]$. Studies have shown that microalgal strains are capable of growing well and can fix $\leq 50 \%$ $\mathrm{CO}_{2}$ from exhaust gases, which commonly also contain other contaminants such as $\mathrm{SO}_{\mathrm{x}}$ and $\mathrm{NO}_{x}$ [6]. Some microalgae that show extraordinary capability to fix $\mathrm{CO}_{2}$ include Botryococcus braunii, Chlorella sorokiniana, Chlorella vulgaris, Chlorococcum littorale, Dunaliella tertiolecta, Nannochloropsis oculata, Scenedesmus dimorphus, Scenedesmus obliquus, and Spirulina platensis [14]. Table 1 lists the microalgae studied for their potential to fix $\mathrm{CO}_{2}$.

Table 1. $\mathrm{CO}_{2}$ tolerance and uptake by various microalgae.

\begin{tabular}{|c|c|c|c|}
\hline Microalgae Species & $\begin{array}{c}\mathrm{CO}_{2} \text { Concentration } \\
(\%)\end{array}$ & $\begin{array}{l}\mathrm{CO}_{2} \text { Fixation Rate } \\
\left(\mathrm{g} \mathrm{L}^{-1} \text { day }^{-1}\right)\end{array}$ & Reference \\
\hline Chlamydomonas sp. & 15 & - & [15] \\
\hline \multirow{6}{*}{ Chlorella sp. } & 40 & - & [16] \\
\hline & 0.03 & 1.62 & [17] \\
\hline & 15 & - & [18] \\
\hline & 15 & 0.46 & [19] \\
\hline & 5 & 0.7 & [20] \\
\hline & - & 1.38 & [21] \\
\hline
\end{tabular}


Table 1. Cont.

\begin{tabular}{|c|c|c|c|}
\hline Microalgae Species & 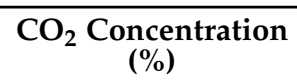 & $\begin{array}{c}\mathrm{CO}_{2} \text { Fixation Rate } \\
\left(\mathrm{g} \mathrm{L} \mathrm{L}^{-1} \text { day }^{-1}\right)\end{array}$ & Reference \\
\hline Chlorella kessleri & 18 & 0.16 & {$[22]$} \\
\hline Chlorella (marine) & $2-15$ & $2.14-4.69$ & [23] \\
\hline Chlorella pyrenoidosa SJTU-2 & $5-50$ & $0.029-0.71$ & {$[24]$} \\
\hline \multirow{3}{*}{ Chlorella vulgaris } & 10 & 0.25 & [10] \\
\hline & 2 & 0.43 & {$[25]$} \\
\hline & 18 & - & [22] \\
\hline \multirow{2}{*}{ Chlorococcum littorale } & 20 & 0.246 & [26] \\
\hline & 60 & - & [27] \\
\hline Chroococcus cohaerens & 0.03 & 0.78 & [17] \\
\hline Cyanidium caldarium & 100 & - & [28] \\
\hline Dunaliella sp. & 3 & 0.31 & [29] \\
\hline \multirow{2}{*}{ Dunaliella tertiolecta } & 10 & 0.27 & [10] \\
\hline & 15 & 5.82 & [30] \\
\hline Eudorina sp. & 20 & - & [16] \\
\hline Euglena gracilis & 45 & - & [31] \\
\hline Haematococcus pluvialis & 34 & 0.14 & [32] \\
\hline Microcystis aeruginosa & 15 & 0.134 & [19] \\
\hline Microcystis ichthyoblabe & 15 & 0.142 & [19] \\
\hline Nannochloris sp. & 15 & - & [33] \\
\hline Phaeodactylum tricornitum & 15 & 0.59 & {$[30]$} \\
\hline Phormidium sp. & 15 & 7.39 & [30] \\
\hline \multirow{2}{*}{ Scenedesmus sp. } & 80 & - & [16] \\
\hline & 15 & 0.61 & [19] \\
\hline Scenedesmus dimorphus & 0.03 & 1.27 & [17] \\
\hline Scenedesmus incrassatulus & 0.03 & 1.50 & [17] \\
\hline \multirow{5}{*}{ Scenedesmus obliquus } & 15 & 4.6 & [30] \\
\hline & 10 & 0.55 & [34] \\
\hline & 10 & 0.29 & {$[24]$} \\
\hline & 2.5 & 1.19 & [35] \\
\hline & 18 & - & {$[22]$} \\
\hline Synechococcus elongatus & 60 & - & [36] \\
\hline Spirulina sp. & 20 & 0.14 & [37] \\
\hline Spirulina platensis & 15 & 0.92 & {$[38]$} \\
\hline Tetraselmis sp. & 14 & - & [39] \\
\hline
\end{tabular}

Although different algal species are reported to withstand high concentrations of $\mathrm{CO}_{2}$, their enhanced growth and maximum biomass yield are largely observed only at $\mathrm{CO}_{2}$ concentrations of $10-40 \%$. Many studies indicate that the $\mathrm{CO}_{2}$ concentration alone cannot be directly correlated to biomass productivity, but other factors such as the tolerance limit of algae to $\mathrm{CO}_{2}$ and its utilization rate also play key roles in algal productivity [22,40-42]. Furthermore, high photosynthetic efficiency of microalgae converts $\mathrm{CO}_{2}$ to biomass rich in carbohydrates such as starch, cellulose, and various fermentable sugars via Calvin cycle [34,43], which is followed by metabolic pathways such as glycolysis and TCA cycle, resulting in lipid biosynthesis, stored as triacylglycerols and protein synthesis (Figure 1). It is well established that $\mathrm{CO}_{2}$ plays a major role in building up of the important primary metabolites in microalgal species. This has been demonstrated by Sivakumar et al. [37] using a cyanobacterial species Spirulina sp. (MCRC-A0003) that has shown to exhibit 
good tolerance to high $\mathrm{CO}_{2}$ concentrations (up to 50\%) with low biomass yield. However, lower concentrations of $\mathrm{CO}_{2}(4-20 \%)$ have shown to support increased yields of biomass, chlorophyll, protein, and carbohydrate.

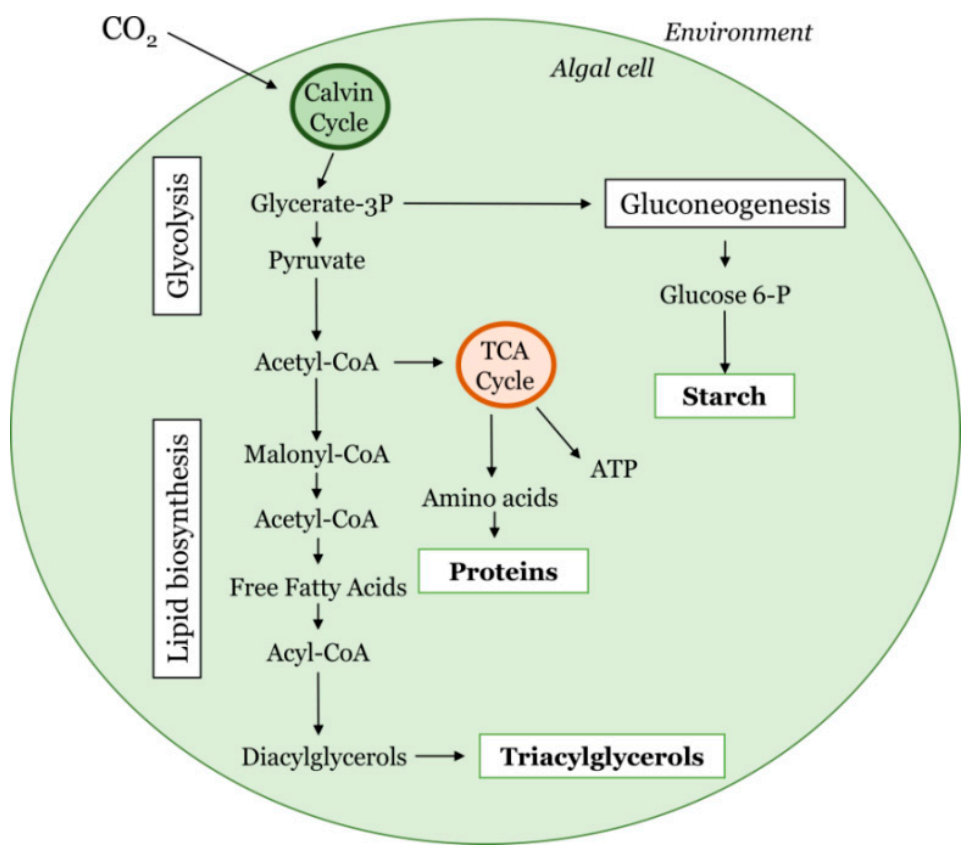

Figure 1. Carbon metabolism in microalgae (adopted from [44]).

Different microalgal species have shown different tolerance limits and fixation rates (200-1000 $\mathrm{mg} \mathrm{L}^{-1} \mathrm{day}^{-1}$ ) of $\mathrm{CO}_{2}$ present in flue gas, which was interestingly pronounced in mutated strains of the respective species $[10,14,45,46]$. Sydney et al. [10] evaluated five microalgal species suitable for large-scale cultivation, which exhibited considerable variations in $\mathrm{CO}_{2}$ fixation rates in the order: Dunaliella tertiolecta SAD-13.86 (272.4 $\mathrm{mg} \mathrm{L}^{-1}$ day $\left.^{-1}\right)$, Chlorella vulgaris LEB-104 (252 mg L ${ }^{-1}$ day $\left.^{-1}\right)$, Spirulina platensis LEB-52 $\left(319 \mathrm{mg} \mathrm{L}^{-1}\right.$ day $\left.^{-1}\right)$, Botryococcus braunii SAG-30.81 (497 $\mathrm{mg} \mathrm{L}^{-1}$ day $^{-1}$ ), and Chlorococcum littorale $\left(1000 \mathrm{mg} \mathrm{L}^{-1}\right.$ day $\left.^{-1}\right)$.

\section{Microalgae-Based Wastewater Treatment}

As early as in the 1960s, researchers of University of California at Berkley, USA designed an indigenous biological wastewater treatment system that used microalgae [47]. Generally, the tertiary treatment processes are developed to remove nutrients such as ammonia, nitrate, and phosphate, and they are nearly four times costlier than the primary treatment methods. However, microalgal cultures with the ability to consume inorganic nitrogen and phosphorus for their growth offer a simple and cost-effective solution to tertiary treatment processes [48]. In these treatment systems, microalgae are grown in highrate raceway ponds, primarily to remove nitrogen and phosphorus and improve dissolved oxygen levels that promote growth of aerobic bacteria, which, in turn, decompose organic wastes and stabilize the treated water for reuse in irrigation [49].

Algae-based wastewater treatment methods are advantageous than the conventional chemical-based treatment processes due to their simple and lower-level technology with minimal $\mathrm{CO}_{2}$ footprint, significant cost saving potential, and effective carbon, nutrient, and pathogen removal [50]. In the conventional treatment process, aeration is essential for effective utilization of organic and inorganic components by aerobic bacteria [51], and the average energy consumption for aeration of a municipal wastewater typically having $400-500 \mathrm{mg} \mathrm{COD} \mathrm{L}^{-1}$ varies from 0.25 to $1.89 \mathrm{kWhm}^{-3}[52,53]$. However, generation of a significant amount of dissolved oxygen in the algae-based treatment process during the photosynthetic growth of algae negates the need for a separate mechanical aeration process, 
thus reducing the high operational cost [54]. Furthermore, algae-based treatment system is eco-friendly and sustainable, as no sludge is generated, and it also helps in effective recycling of nutrients. In other words, the algal biomass rich in $\mathrm{N}$ - and P-nutrients recovered from wastewater can be used as animal feed or as low-cost organic fertilizer [51,55], whereas in the conventional activated sludge process, phosphorus removal in particular is challenging [56]. Chlorella sp. and Scenedesmus sp. are the two microalgal species that are explored extensively due to their potential to remove nutrients such as nitrates, phosphates, sulphates, etc. and COD from various wastewaters. Ansari et al. [57] have shown accelerated growth of Chlorella and Scenedesmus species with lipid accumulation when grown in raw wastewater obtained from a septic tank by removing nutrients such as phosphates $(70 \%)$, nitrates $(98 \%)$, sulphates $(100 \%)$, and COD $(84 \%)$.

Anaerobic digestion (AD) of maize silage, animal manure, dairy and municipal wastewater and sludge, food wastes, etc. is one of the promising sustainable methods for the treatment of high organic wastes. However, the nutrient-rich liquid digestate (LD) produced during $\mathrm{AD}$ is highly turbid and unfit for direct discharge into water bodies. Recent studies have proven that the microalgae cultivation in LD is a potential solution for its treatment, as well as valorization [58-60]. Krzemińska et al. [61] studied the effect of LD from anaerobic fermentation of maize silage on the growth rates and macro and micronutrient removal efficiency of Auxenochlorella protothecoides and showed that the alga can proliferate and accumulate lipids. Additionally, they observed reduced PUFA and increased MUFA levels, which contribute to triacylglycerols (TAG), a good source for the production of biofuels.

The highest biomass production of microalgae $C$. vulgaris and A. platensis was achieved when their growth media were supplemented with $50 \%$ distilled liquid digestate (DLD). C. vulgaris showed highest ammonia (71.2\%) and total nitrogen (47.1\%) removal efficiencies at N/P ratio of 10.3 and A. platensis recorded $66.4 \%$ total nitrogen removal at N/P ratio of 32.2 [62]. Nitrogen removal efficiency by algae is reported to be better at low N/P ratio, and complete removal cannot be achieved when the culture medium is phosphoruslimited [63,64]. In other words, phosphorus and nitrogen metabolisms are interrelated, as the absence or abundance of either of them is of very little use [65]. This is well established by Shashirekha et al. [66] by cultivating Scenedesmus sp. in sugar mill effluent with varying nitrogen and phosphorus concentrations. They reported that maintaining the carbonnitrogen-phosphorus ratio is essential to promote the growth of microalga in wastewater, which, in turn, showed notable reduction in the values of nutrients such as carbonates, nitrates, phosphates, magnesium, sodium, etc., all recording below the detectable limit, indicating their complete utilization by the microalga.

In addition to efficient nutrient removal, there are certain other advantages in using microalgae in wastewater treatment over the conventional technologies. They include: (i) cost-effectiveness-owing to efficient harnessing of naturally available solar energy and utilization of organic carbon from wastewaters, (ii) $\mathrm{CO}_{2}$ biofixation through photosynthesis, (iii) stabilized wastewater with improved dissolved oxygen that can be discharged into water bodies safely, and (iv) economic value addition to the algal by-products [67]. The biomass serves as potential feedstock for bioenergy production (biohydrogen, biomethane, biodiesel, bioethanol, etc.) and hence is considered a prospective renewable alternative to non-renewable fossil fuels $[68,69]$. Processing algal biomass generated in wastewater through lipid trans-esterification, carbohydrate fermentation, or anaerobic digestion is considered sustainable for bioenergy production [70]. Among them, anaerobic digestion is more promising and viable because a wide range of microalgae with varied biochemical make up can be employed as feed stock [71].

The use of native species for wastewater treatment is normally preferred due to their adaptation capabilities to the local biotic and abiotic conditions and non-invasive or non-noxious nature. These versatile indigenous organisms with higher production rates, isolated from dynamic natural ecosystems, are suitable for bioprocesses that require high biomass productivity than the commonly cultivated isolates [72,73]. 


\section{Factors Influencing Algal Cultivation in Wastewater and $\mathrm{CO}_{2}$ Uptake}

Cultivation of algae in wastewaters, their potential to uptake $\mathrm{CO}_{2}$, and optimization of strain-specific growth are governed by a number of interrelated factors that play a critical role $[55,67]$. Some of them that either positively influence or negatively limit algal growth include (i) their structural and genetic make up-that contribute to cell size, density, and fragility, vis à vis their ability to tolerate and/or adapt to varying wastewater quality; (ii) mode of growth - phototrophy, heterotrophy, or mixotrophy; (iii) concentration and proportion of major nutrients, viz., $\mathrm{C}-\mathrm{N}-\mathrm{P}$ ratio, inorganic carbon and other micronutrients; (iv) temperature; (v) pH; (vi) $\mathrm{CO}_{2}$ concentration; (vii) composition of flue gas; and (viii) availability of light (day-night cycle and irradiation intensity).

\subsection{Algal Strains}

The foremost and critical step in Algal Biotechnology is the screening of algal strain for a particular application that can be cultured at large-scale. It should be rugged-natured to withstand varying environmental conditions, have an inherent ability to produce a large quantity of biomass with high growth rate, and should be easily harvestable. For example, Botryococcus braunii, Chlorella sp., and Scenedesmus sp. are reported as ideal candidates in numerous studies pertaining to $\mathrm{CO}_{2}$ bio-mitigation and biofuel generation. Few microalgal strains exhibit high growth rates in addition to their capability to survive stringent environments such as seawater having salinity of $35 \%$, alkaline lake water having $\mathrm{pH} \geq 8.5$, and even certain industrial effluents containing higher levels of salts and other nutrients. Their ingrained biochemical profiles with variety of metabolites such as polysaccharides, fatty acids, proteins, essential amino acids, polypeptides, pigments, vitamins, minerals, etc. also serve as raw materials for (i) bioenergy, viz., trans-esterified biodiesel, fermented bioethanol, photobiological hydrogen, anaerobically produced methane and hydrocarbon biofuels; (ii) feed source for aquatic lives such as fish, shrimp, prawn, etc. and for higher animals such as poultry, cattle, etc.; (iii) high-quality applications such as medicines or nutraceutical (e.g., omega-3 fatty acids); and (iv) organic fertilizers, etc. [74-77].

\subsection{Mode of Microalgal Growth}

Algae use solar energy, $\mathrm{CO}_{2}$, and water during photosynthesis to synthesize glucose, which is then converted to pyruvate releasing adenosine triphosphate (ATP) and $\mathrm{O}_{2}$. The conversion of solar energy into chemical energy is mediated by the green pigment chlorophyll. All algae use chlorophylla $(\mathrm{chl} a)$ to collect photosynthetically active light to absorb its energy from the violet-blue and orange-red wavelengths and a small amount from the intermediate (green-yellow-orange) wavelengths. Besides chl $a$, some green algae and euglenophytes also use chlorophyllb (chlb) and other chlorophylls in different combinations, chlorophyllides, carotenoids, and phycobiliproteins to gather further light from wavelengths of the spectrum that are not absorbed by chla [78].

Generally, algal growth takes place through autotrophic, heterotrophic, mixotrophic, and photoheterotrophic modes. While light is the sole energy supply for $\mathrm{CO}_{2}$ fixation in photoautotrophic cultures, organic or inorganic carbon, carbonates, etc. form the energy sources in heterotrophic mode [79]. Therefore, the latter results in higher growth rate when compared to the former mode. In mixotrophy, both autotrophy and heterotrophy operate simultaneously [80]. The microalgae such as Chlamydomonas globosa, Chlorella minutissima, and Scenedesmus bijuga, when grown under mixotrophic conditions, resulted in 3-10 times more biomass production with higher bioenergetics (lipid productivity) than under phototrophic condition [81]. According to Márquez-Rocha [82], this is due to the net photoautotrophic growth of microalga under light condition followed by heterotrophic growth under dark condition. This phenomenon was reported in Scenedesmus obliquus when cultivated in sugar mill effluent; it exhibited a versatile nature of shifting from phototrophy to heterotrophy depending on the availability of light and carbon sources [66]. 


\subsection{Nutrients}

The major nutrients generally needed by algae for their growth are $\mathrm{C}, \mathrm{N}, \mathrm{P}$, and $\mathrm{K}$, as well as a few other trace elements such as $\mathrm{Mg}$ and $\mathrm{Fe}$, depending on the specific requirement of each algal species. Organic carbon and inorganic carbon such as carbonates, bicarbonates, and gaseous $\mathrm{CO}_{2}$ are different carbon sources available for microalgal growth. Ammonium is the most commonly used and preferred form of nitrogen, as it requires less energy for assimilation and is readily absorbed by microalgae. It is followed by $\mathrm{NO}_{3}{ }^{-}, \mathrm{NO}_{2}{ }^{-}$, and urea. However, in some microalgae, an $\mathrm{NH}_{4}{ }^{+}$concentration $>100 \mathrm{mg} \mathrm{L}^{-1}$ is shown to inhibit their growth. This is due to speciation of $\mathrm{NH}_{4}{ }^{+}$and conversion of $\mathrm{NH}_{4}{ }^{+}$to $\mathrm{NH}_{3}$ under alkaline conditions or at elevated temperatures [83]. Qin et al. [84] studied the treatment of dairy digestate using biological aerated filter (BAF) with enriched nitrobacteria followed by C. pyrenoidosa cultivation. The pre-treatment using BAF coupled with nitrobacteria rapidly nitrified the ammonia nitrogen in digestate and improved the light transmittance, indicating that the ammonia nitrogen is almost completely converted into nitrate nitrogen, resulting in elimination of ammonia inhibition for C. pyrenoidosa. Phosphorus is another essential nutrient, which is part of DNA, RNA, ATP, and cell membrane components, which greatly impacts the growth and metabolism of microalgae. It is normally available in the wastewaters as inorganic anions such as $\mathrm{H}_{2} \mathrm{PO}_{4}{ }^{-}$and $\mathrm{HPO}_{4}{ }^{2-}[74,85]$.

Agricultural fertilizers such as NPK are commonly used to maintain steady growth [86-88]. Wastewaters rich in organic and inorganic nutrients can also be used as substitutes to freshwater amended with chemical components [81]. Unicellular microalgae belonging to Chlorophyta, particularly Scenedesmus sp. and Chlorella sp., are versatile and tolerant to various types of wastewaters and are highly efficient in removing nutrients from them [89]. Chlorella minutissima is shown to thrive even in raw sewage and further dominate in the subsequent oxidation pond systems. This is because C. minutissima can grow mixotrophically in light as well as in dark, utilizing a variety of organic carbon, ammonia, or nitrate as a nitrogen source and survive over a wide $\mathrm{pH}$ range [90]. Much research in the recent past demonstrates the cultivation of various microalgae in different wastewaters such as agricultural run-off, aquaculture, dairy, municipal sewage, palm oil, paper and pulp, poultry, swine effluent, etc. by assimilating C-N-P and other chemical components (Table 2).

Table 2. Microalgae cultivated in wastewater.

\begin{tabular}{ccc}
\hline Nature of Effluent & Microalga & References \\
\hline Agricultural run-off & Chlorella vulgaris & {$[91]$} \\
\cline { 1 - 3 } Agro-industrial wastewater & $\begin{array}{c}\text { Chlorella vulgaris, } \\
\text { Scenedesmus obliquus }\end{array}$ & {$[50]$} \\
\hline Aquaculture wastewater & $\begin{array}{c}\text { Chaetoceros calcitrans, } \\
\text { Nannochloris maculate, } \\
\text { Tetraselmischuii }\end{array}$ \\
\hline Aquaculture wastewater & $\begin{array}{c}\text { Algae consortium-Chlorella } \\
\text { saccharophila UTEX 2911, }\end{array}$ & {$[93]$} \\
Dairy farm wastewater & $\begin{array}{c}\text { Chlamydomonas pseudococcum UTEX } \\
\text { 214, Scenedesmus sp. UTEX 1185 }\end{array}$ & {$[94]$} \\
\hline Digested distillery effluent & Spirulina platensis & {$[96]$} \\
\hline Food waste and & Chlorella sorokiniana & \\
\hline municipal wastewater & S
\end{tabular}


Table 2. Cont.

\begin{tabular}{|c|c|c|}
\hline Nature of Effluent & Microalga & References \\
\hline \multirow{3}{*}{ Municipal wastewater } & Chlorella minutissima & [90] \\
\hline & $\begin{array}{c}\text { Auxenochlorella protothecoides } \\
\text { UMN280 }\end{array}$ & [97] \\
\hline & Scenedesmus sp. AMDD & [49] \\
\hline \multirow{2}{*}{ Palm oil mill effluent } & Chlorella sorokiniana & [98] \\
\hline & Chlorella sp. & [99] \\
\hline \multirow[t]{2}{*}{ Paper and pulp mill effluent } & $\begin{array}{c}\text { Oscillatoria chlorina, } \\
\text { Scenedesmus quadricauda }\end{array}$ & [100] \\
\hline & Scenedesmus sp. & [101] \\
\hline $\begin{array}{l}\text { Poultry litter anaerobic } \\
\text { digestion effluent }\end{array}$ & $\begin{array}{l}\text { Chlorella minutissima, } \\
\text { Chlorella sorokiniana, } \\
\text { Scenedesmus bijuga }\end{array}$ & [102] \\
\hline Sugar mill effluent & Scenedesmus obliquus & [66] \\
\hline Sweetmeat factory waste media & Scenedesmus obliquus & [103] \\
\hline \multirow{3}{*}{ Swine wastewater } & Chlorella sp. & {$[104,105]$} \\
\hline & $\begin{array}{l}\text { Chlorella vulgaris, } \\
\text { Chlamydomonas reinhardtii, } \\
\text { Chlamydomonas debaryana }\end{array}$ & [106] \\
\hline & Scenedesmus sp. & [107] \\
\hline Tannery—soak liquor & Spirulina sp., Nannochloropsis sp. & [108] \\
\hline
\end{tabular}

The adaptability of Scenedesmus obliquus in sugar mill effluent studied at laboratory by Shashirekha et al. [66] reports that the ratio of $0.1 \mathrm{C}: 0.07 \mathrm{~N}$ : $0.04 \mathrm{P}$ is optimum for algal growth to achieve a biomass yield of $1.23 \mathrm{~g} \mathrm{~L}^{-1}$. They also demonstrated the algal cultivation at pilot-scale by combining two processes - (i) sequestration of $\mathrm{CO}_{2}$, the gaseous exhaust generated by fermentation process at distillery, and (ii) treatment of effluent, the liquid waste discharged from sugar mill. Through this eco-friendly approach, the $\mathrm{pH}$ was stabilized to neutral, EC, salinity, and TDS reduced by $50-60 \%$, COD and sugar content reduced by $80-85 \%$, and DO level improved significantly, besides generating $\sim 0.5 \mathrm{~kg}$ (dry wt.) algal biomass $\mathrm{m}^{-3}$ of effluent.

Chlorella vulgaris cultivated in nitrogen-rich, pretreated liquid digestate showed a net biomass yield of 10-14 $\mathrm{g} \mathrm{L}^{-1}$ (DW) and a productivity of up to $0.93 \mathrm{~g} \mathrm{~L}^{-1} \mathrm{~d}^{-1}$ [109]. Unicellular microalgae such as Chlorella sp., Scenedesmus obliquus, Scenedesmus quadricauda, Scenedesmus dimorphus, and Oocystis sp. subjected to long-term acclimation to anaerobic digestate of food waste and found that Oocystis sp. proliferated in the effluent containing high ammoniacal nitrogen $\left(600 \mathrm{mg} \mathrm{L}^{-1}\right)$ displaying high tolerance [60]. In general, the algal biomass production can range from 9.6-42 tons ha ${ }^{-1}$ year $^{-1}$ depending on the environmental conditions such as light intensity, temperature, rainfall patterns, and other factors such as water quality, availability of nutrients, $\mathrm{CO}_{2}$, etc. In the open environment, they have the capability to sequester 322 tons $\mathrm{C} \mathrm{ha}^{-1}$ year $^{-1}$. Intensification of the cultivation process could result in increased biomass yield up to 100 tons ha $^{-1}$ year ${ }^{-1}$ by sequestering up to 1500 ton $C$ ha $^{-1}$ year ${ }^{-1}$.

\subsection{Temperature}

Temperature is one of the important environmental factors that influence $\mathrm{CO}_{2}$ as well as nutrient solubility. At higher temperature, the $\mathrm{CO}_{2}$ solubility decreases. In an open pond system, this leads to the escape of $\mathrm{CO}_{2}$ into the atmosphere [110,111]. With varying temperatures, the insoluble solids and other components can contribute to dark coloration, especially in the waste streams, leading to absorbance of light of certain wavelength, 
reducing the available light energy impacting photosynthesis of algae [112]. Temperature also affects all the metabolic activities of algal cell by highly influencing the cell composition, nutrient and $\mathrm{CO}_{2}$ uptake, and ultimately, the growth rate. The optimal temperature for algal growth broadly varies from $20-35^{\circ} \mathrm{C}$. Although the algal productivity increases with increasing temperature, beyond the optimum range, photorespiration negatively impacts its productivity [113]. Microalgal culture such as Haematococcus pluvialis grows actively at lower temperature ranges $15-20^{\circ} \mathrm{C}[114,115]$. However, Fan et al. [116] reported a steady raise in photosynthetic oxygen evolution, with maximum algal growth rate and doubling time of $12 \mathrm{~h}$ within the temperature range of $25-28{ }^{\circ} \mathrm{C}$ and a gradual drop from 28 to $33^{\circ} \mathrm{C}$ and a steep drop at higher temperatures. They observed $28^{\circ} \mathrm{C}$ to be the optimum for photosynthesis. However, the temperature-dependent growth rate differs with each species. Torzillo and Vonshak [117] measured the oxygen evolution rate by Spirulina at different temperatures and found that the respiration rate increases with increasing temperature. In general, it is important to select the algal species that can withstand high temperatures, especially when they are used for $\mathrm{CO}_{2}$ fixation from flue gas generated from industries.

\section{5. $p H$}

$\mathrm{pH}$ is yet another key feature that determines the algal growth. Different species have different $\mathrm{pH}$ requirements, though most of them are reasonably tolerant to $\mathrm{pH}$ variations. In most cases, fresh water eukaryotic algae can grow well in slightly acidic environments (with $\mathrm{pH}$ around 6.5-6.8); however, alkaline conditions ( $\mathrm{pH} 7-9$ ) are mostly desired by cyanobacteria. The high metabolic rates during active growth phase of alga result in the liberation of $\mathrm{OH}^{-}$ions into the media that contributes to its increased $\mathrm{pH}$ [118]. Chlorella vulgaris is studied extensively as model microalgal species for the effect of $\mathrm{pH}$ on its growth; although it can grow in wide $\mathrm{pH}$ range, higher growth and biomass yields are reported to be best between 7.5 and $9.5[119,120]$. Studies by Razzak et al. [74] also reported similar results, where the $\mathrm{pH}$ values 7.5 and 8.0 have shown to promote maximum growth of Chlorella vulgaris.

\section{6. $\mathrm{CO}_{2}$ Concentration}

Typically, microalgal biomass is composed of $\sim 50 \%$ carbon, which is mostly derived from $\mathrm{CO}_{2}$. Under ideal conditions during daylight hours, it is estimated that 1 ton of algal biomass (on dry weight basis) is produced by fixing 1.83 tons of $\mathrm{CO}_{2}$ that is fed continuously into the algal cultivation system. $\mathrm{CO}_{2}$ feeding to the algal cultivation system can be assisted with $\mathrm{pH}$ measurements in a controlled manner, which helps minimize $\mathrm{CO}_{2}$ losses [74]. In general, $\mathrm{CO}_{2}$ has higher solubility (over 100 times than $\mathrm{O}_{2}$ ), i.e., $1.496 \mathrm{~g} \mathrm{CO}_{2} \mathrm{~L}^{-1}$ water at $25^{\circ} \mathrm{C}$ and $1 \mathrm{~atm} . \mathrm{CO}_{2}$ mass transfer into the aqueous phase dependents on parameters such as its concentration at gas phase, area availability at gas-liquid interface, contact time, properties of solution including $\mathrm{pH}$, temperature, amount of dissolved salts in it, etc. The $\mathrm{CO}_{2}$ mass transfer rate is calculated by the two-film theory formula:

$$
\mathrm{N}_{\mathrm{CO}_{2}}=\mathrm{k}_{\mathrm{L}} \alpha\left(\mathrm{C}_{\mathrm{CO}_{2}} \mathrm{~L}^{*}-\mathrm{C}_{\mathrm{CO}_{2}} \mathrm{~L}\right)
$$

where $\mathrm{k}_{\mathrm{L}}=$ liquid phase mass transfer coefficient, $\alpha=$ specific area, $\mathrm{C}_{\mathrm{CO} 2} \mathrm{~L}^{*}=\mathrm{CO}_{2}$ concentration in the liquid that equilibrates its actual partial pressure on the gas phase, and $\mathrm{C}_{\mathrm{CO} 2} \mathrm{~L}=$ actual $\mathrm{CO}_{2}$ concentration in liquid [111,121].

A study reports that, although both Scenedesmus sp. and Chlorella sp. have the ability to grow well in lower dosages of $\mathrm{CO}_{2}(10-30 \%)$, at high concentrations (up to $80 \%$ ), the former is more tolerant than the latter microalga [16]. A similar trend was reported in Spirulina sp. (MCRC-A0003), which exhibited tolerance to $\mathrm{CO}_{2}$ concentration as high as $50 \%$; however, much uptake was observed only at $10-20 \%$ concentrations leading to maximum biomass yield [37]. According to a study by Patil and Kaliwal [122], $15 \% \mathrm{CO}_{2}$ is optimal to fix $0.12 \pm 0.002 \mathrm{~g} \mathrm{CO}_{2} \mathrm{~L}^{-1}$ day $^{-1}$ by Scenedesmus bajacalifornicus BBKLP-07 to obtain a biomass yield of $0.061 \pm 0.008 \mathrm{~g} \mathrm{~L}^{-1}$ day $^{-1}$. Although Euglena gracilis shows high $\mathrm{CO}_{2}$ tolerance up to $45 \% \mathrm{CO}_{2}$ and survive well, excellent growth is achieved at $5 \% \mathrm{CO}_{2}$ concentration, [31]. With stage-wise adaptation, Chlorococcum littorale is demonstrated to grow utilizing $\mathrm{CO}_{2}$ 
up to $60 \%$ [27]. A mutant strain KR-1 of Chlorella sp. is reported to grow even at $70 \% \mathrm{CO}_{2}$ levels [123].

\subsection{Composition of Flue Gas}

Typically, flue gas generated from industries consists of a mixture of $\mathrm{CO}_{2}$ and $\mathrm{N}_{2}$ and small amounts of $\mathrm{CO}, \mathrm{NO}_{\mathrm{x}}, \mathrm{SO}_{\mathrm{x}}$ and water vapor. The algal culture does not require high purity of $\mathrm{CO}_{2}$ gas, and therefore, flue gas with about $2-5 \% \mathrm{CO}_{2}$ concentration can be used as $\mathrm{CO}_{2}$ source for its cultivation. The ability of microalgae to use $\mathrm{NO}_{\mathrm{x}}, \mathrm{SO}_{\mathrm{x}}$, and certain other combustion products aids to reduce an additional process of flue gas scrubbing [124].

Earlier studies revealed that direct feeding of flue gas into microalgal cultivation ponds increases biomass production by $30 \%$ in comparison to the injection of an equivalent quantum of pure $\mathrm{CO}_{2}$ [125]. This could be due to the stimulant effect of flue gas having the supplemental nutrients (sulfur and nitrate). However, many researchers consider that it is very important to study the impact of $\mathrm{NO}_{x}$ and $\mathrm{SO}_{\mathrm{x}}$ on $\mathrm{CO}_{2}$ uptake by microalgae, although they are present in trace quantities. The growth of many microalgal strains is reported to be critically inhibited by flue gas with $50 \mathrm{ppm} \mathrm{SO}_{\mathbf{x}}$ [26]. Hence, direct fixation of $\mathrm{CO}_{2}$ from flue gas by microalgae may only be possible with the gas mixture having $<50 \mathrm{ppm} \mathrm{SO}$. Similarly, the effect of $\mathrm{NO}_{x}$ on microalgal growth has been explored by many researchers. According to Yoshihara et al. [33], Nannochloris sp. could survive well only in nitric oxide (NO) concentrations $<100 \mathrm{ppm}$. On the contrary, few other reports suggest that some species of microalgae can tolerate high concentrations of other gases present in flue gas. It is interesting to note that Dunaliella tertiolecta could remove even up to $96 \%$ of $1000 \mathrm{ppm} \mathrm{NO}$ from the flue gas when the mixture also contained $15 \% \mathrm{CO}_{2}$ [40]. Tetraselmis sp. was able to grow well utilizing $14.1 \% \mathrm{CO}_{2}, 185 \mathrm{ppm}$ of $\mathrm{SO}_{\mathrm{x}}$, and $125 \mathrm{ppm}$ of $\mathrm{NO}_{x}$ from the flue gas [39]. The growth of Chlorella sorokiniana in the serially connected airlift reactors was studied by passing the flue gas from oil producing industries, it was found that the alga could remove about $74 \%$ of $\mathrm{CO}_{2}$ [38].

\subsection{Light}

The photosynthetic apparatus of algae exercises enormous dynamics and flexibility responding to varying environmental conditions, viz., light intensity, nutrient availability, etc. The responses involve re-organising few photosynthetic complexes frequently mediated by post-translational alterations of their subunits by extensive signaling network within the chloroplasts, as well as between chloroplasts and nucleus that modulates nuclear and plastid gene expression. Under limited light conditions, the photosynthetic apparatus optimizes the light absorption efficiency of the alga by adjusting the relative size of its antenna systems through the reversible allotment of a portion of Light-Harvesting Complex system II between Photosystems I and II, a process occurring in cyanobacteria, algae, and plants referred to as state transitions. When the absorbed light energy exceeds the capacity of the photosynthetic apparatus, the excess excitation energy is dissipated as heat by the non-photochemical quenching mechanism to avoid photo damage of cells [126-129].

One of the foremost criteria for economic viability of microalgal cultivation systems is efficient harnessing of solar radiation by the cells. A cost-effective open or closed system is characterized by a high surface area and biomass yield, which can be accomplished by establishing a culture system with optimal solar irradiation regime [74]. A study with Nannochloropsis culture has demonstrated that, with increasing cell density, the light penetration into the culture drops exponentially, which is highly pronounced with green light with wavelength 580-600 nm [130]. Different microalgal species adjust themselves to the changing light intensity, e.g., low light intensities $\left(\sim 10 \mathrm{mmol}\right.$ photons $\left.\mathrm{m}^{-2} \mathrm{~s}^{-1}\right)$ are normally desired by species having phycobilisomes, whereas higher range $(\sim 60-100 \mathrm{mmol}$ photons $\mathrm{m}^{-2} \mathrm{~s}^{-1}$ ) are often preferred by strains such as dinoflagellates. In general, 10-30 mmol photons $\mathrm{m}^{-2} \mathrm{~s}^{-1}$ is proven to be ideal for large number of species for their sustained cultivation. On the contrary, Daliry et al. [120] reported that 100-140 mmol photons $\mathrm{m}^{-2} \mathrm{~s}^{-1}$ favored the growth of Chlorella vulgaris, achieving maximum biomass and lipid productivity. 


\section{Microalgae in Wastewater Treatment}

The biggest practical challenge in mass cultivation of algae is the method of cultivation, which is largely dependent on the availability of water. To cultivate algae in open ponds, enormous amounts of water ( 11-13 million liters per hectare) and macronutrients are required, which contribute to $10-20 \%$ of the total production cost. A recent estimate shows that the average cost for cultivation of algae is EUR $10 \mathrm{~kg}^{-1}$, of which a considerable part accounts to nutrient inputs. Given such huge requirements of water and chemical nutrients, wastewaters with abundant organic $(\mathrm{C}, \mathrm{N}$, and $\mathrm{P})$ and inorganic nutrients serve as best substitutes [81,112,131], and the costs can be reduced to less than EUR $5 \mathrm{~kg}^{-1}$ [112,132,133]; a few reports on microalgae-based wastewater treatments are summarized in Table 2. Due to the nutrient removal efficiency, microalgal cultivation in wastewater reduces the requirement of chemicals for their growth, thereby providing the additional advantage of eco-friendly wastewater treatment. In addition, the oxygen produced during photosynthetic activity of microalgae enriches the growth of co-existing bacteria; thereby, both microalgae and bacteria synergistically help in remediation of wastewater.

\section{Synergistic Effect of Algal-Bacterial Co-Cultivation in Wastewater}

Employing algal-bacterial consortial systems in wastewater treatment has become extensively popular from as early as the 1950s due to their high efficiency to remove nutrients and other pollutants, in addition to plenty of environmental advantages. The energy nexus of this symbiotic combination is an important strategy, as the microalgae use $\mathrm{CO}_{2}$ generated by bacteria during respiration as their carbon source, and bacteria, in turn, derive their energy from $\mathrm{O}_{2}$ produced by microalgae during photosynthesis $[134,135]$. The carbonic anhydrase (CA) metalloenzymes aid $\mathrm{CO}_{2}$ uptake by algal cells by catalyzing reversible hydration of $\mathrm{CO}_{2}$ to bicarbonate $\left(\mathrm{CO}_{2}+\mathrm{H}_{2} \mathrm{O} \leftrightarrow \mathrm{HCO}_{3}{ }^{-}+\mathrm{H}^{+}\right)$. There are three different families of $\mathrm{CA}$ enzyme ( $\alpha-\mathrm{CA}, \beta-\mathrm{CA}$, and $\gamma-\mathrm{CA}$ ) distributed variedly in algae and bacteria. While all of them present in microalgae significantly participate in $\mathrm{CO}_{2}$ uptake by the cells, the $\beta$-CA secreted by bacteria augments $\mathrm{CO}_{2}$ fixation in microalgae, in addition to regulating the $\mathrm{pH}$ of the medium in which they exist [136]. By concentrating $\mathrm{CO}_{2}$ as $\mathrm{HCO}_{3}{ }^{-}$in plastids, the $\mathrm{CAs}$ decrease the $\mathrm{CO}_{2}$ diffusion rate from inside the organelle, and thus indirectly help in the lipid production pathway [137]. Some of the algal species exhibit a characteristic elevated extracellular $\mathrm{CA}$ activity responsible for the conversion of $\mathrm{CO}_{3}{ }^{2-}$ to free $\mathrm{CO}_{2}$ and facilitate its assimilation [138]. In an experimental study with the model alga Chlamydomonas reinhardtii, Moroney et al. [139] showed the involvement of $\mathrm{CAs}$ in $\mathrm{CO}_{2}$-concentrating mechanism and a number of other metabolic activities such as photosynthesis, wherein inorganic carbon is transported to actively photosynthesizing cells and a reversible reaction in the respiration process by employing carboxylation or decarboxylation reactions.

In the synergistic algal-bacterial nexus, the bacterial growth degrades complex constituents into simple organic substances, thereby facilitating its uptake by the alga. In general, algal photosynthate contributes to organic loads in wastewaters; however, the bacterial population present in these waters could reduce the net COD loads [140]. Mouget et al. [141] demonstrated that, in addition to $\mathrm{CO}_{2}$ supply, the aerobic bacteria, viz., Pseudomonas diminuta and $P$. vesicularis, reduce the photosynthetic oxygen tension and create a conducive condition within the microenvironment of Scenedesmus bicellularis and Chlorella sp., thereby promoting algal growth. Cho et al. [142] proved that appropriate process optimization and frequent monitoring and recycling of biomass help to maintain the desired algal-bacterial consortium. They assimilate $\mathrm{N}$ and $\mathrm{P}$ present in wastewater, resulting in increased $\mathrm{pH}$ value and oxygenation of organic matter and thus remove fecal coliforms from wastewaters [143].

Ayre et al. [144] cultivated Chlorella sp. in anaerobic digestate of piggery effluent and characterized the bacterial community using $16 \mathrm{~S}$ rRNA sequencing followed by an in silico analysis of functional $\mathrm{N}$ and $\mathrm{C}$ cycling genes and established that Chlorella form symbiotic relationships with many bacterial groups belonging to bacteriodetes, cyanobacteria, and 
nitrifying and $\mathrm{N}$-fixing bacteria and promote $\mathrm{NH}_{4}{ }^{+}$and $\mathrm{NO}_{2}{ }^{-}$removal via nitrification and denitrification pathways, while accumulating $\mathrm{NO}_{3}{ }^{-}$that can be reused as a $\mathrm{N}$ fertilizer. van der Ha et al. [145] demonstrated the better and synergistic performance of methane oxidizing bacteria and microalgae in treating the dissolved methane in anaerobic wastewater in comparison to other aerobic processes, which do not control the escape of methane into the atmosphere. The use of microbiologically active slime and alga combination is still regarded as an effectual and economically viable method for industrial wastewater treatment [146]. Application of algal biofilm technology is yet another recent advancement in wastewater treatment. Typically, extracellular polysaccharides and few other metabolites secreted by algae form biofilm not only participate in the removal of pollutants from wastewater but also help in easy separation of biomass [147].

High metal concentrations could lead to toxicity in algae. However, algal-bacterial consortium mutualistically detoxifies metals in the contaminated sites. The growth of microalgae results in secretion of substances that have a metal chelation property by increasing the $\mathrm{pH}$ of the environment to precipitate heavy metals, which are then easily assimilated by the associated bacteria [148]. On the other hand, bacterial growth has proved to enhance flocculation of algal cells either due to opposite surface charges in their respective cells that aid attraction and binding or secretion of extracellular polysaccharides by bacteria $[134,135]$. This can be effectively tapped for the development of efficient and cost-effective biomass harvesting technique [107].

\section{Algal Cultivation Systems and Possibilities}

Two distinctive cultural systems, namely open raceway pond and closed photobioreactor, are being practiced for growing microalgae and the choice among these depends on the purpose of microalgal cultivation. Although climatic conditions play an important role in maintaining algal culture in open raceway pond, low capital investment and operational costs are the two major advantages in this system. As per literature reports, a typical microalgal raceway pond size ranges between 0.2 and 0.4 ha [149], and so far, the largest commercial raceway established by the Sosa Texcoco Co. near Mexico city for Spirulina cultivation is 900 ha [87]. While the modest open raceway pond is conventionally used for the algal cultivation, particularly in wastewater treatments, this system is not a competent one with regard to $\mathrm{CO}_{2}$ sequestration, as most of $\mathrm{CO}_{2}$ sparged into the algal pond escapes into the atmosphere. However, for such purposes, photobioreactor, being a closed system, is advantageous due to better process control resulting in higher productivity.

\subsection{Open Pond Hybrid Design}

Open raceway ponds are widely being used for large-scale algal cultivation due to their simple construction, relatively easy operation, and economic viability. These ponds could be (a) the simplest unstirred ponds-excavated shallow pits with sloping sides lined with polyethylene sheets [150], (b) square ponds with concentric independent sections -Prakara design developed in MCRC, Chennai [151], (c) circular ponds with about $45 \mathrm{~m}$ diameter-oldest design for large-scale cultivation of algae with agitation by rotating arm, or (d) raceway ponds, the most successful design widely adopted. The raceway type is usually shallow, about $0.15-0.25 \mathrm{~m}$ in depth. They are usually built either as single ' $U$ ' shaped channels with closed circulation of culture or as groups of raceway channels connected together. They are provided with a paddlewheel or agitator at one end for proper circulation and equal mixing of nutrients in water for better algal growth and ' $U$ '-shaped baffles on the other end to regulate the flow of water. The algal productivity in such ponds is shown to be as much as $60-100 \mathrm{mg} \mathrm{L}^{-1}$ day $^{-1}$ on a dry weight basis [87].

\subsection{Photobioreactor Design for $\mathrm{CO}_{2}$ Fixation}

There are many types of photobioreactors (PBRs), including tubular (horizontal, vertical, helical), airlift, bubble column, flat plate, plastic bags, etc. One of the basic characteristic features of PBR is its high surface area per unit volume, designed to maximize the exposure 
of algal cells to light and thus enhance light absorption. In this system, the aqueous medium containing algal culture is circulated within the PBR tubes and the reservoir operated by mechanical or airlift pump. The circulation ensures equal mixing of nutrients, proper aeration, equal exposure of algal cells to light, and maintaining algal cells in suspension without settling. Some of the advantages of PBR include [151,152]:

1. Efficient collection of solar radiation due to narrow gauge of tubes or channels.

2. High areal yields because of high culture densities.

3. Very low contamination risk as they are efficient in maintaining sterility.

4. High biomass yield ensured by proper nutrient mixing and better $\mathrm{CO}_{2}$ conversion.

5. Often easy to operate with process monitoring and control systems.

\subsection{Merits and Demerits}

Some of the merits and demerits of the two systems are highlighted by Soni et al. [153] and given in Table 3.

Table 3. Comparison of open raceway pond and closed photobioreactor.

\begin{tabular}{ccc}
\hline Parameter & Relative Benefit & Remarks \\
\hline Contamination risk & Raceway $>$ PBR & Reduced or nil in PBR \\
\hline Space requirement & Raceway $~$ PBR & Depends on productivity \\
\hline Water loss & Raceway $>$ PBR & Depends on cooling system \\
\hline $\mathrm{CO}_{2}$ loss & Raceway $\sim$ PBR & Depends on $p H$, alkalinity of medium \\
\hline $\mathrm{O}_{2}$ inhibition & Raceway $<$ PBR & Often encountered in PBR \\
\hline Process control & Raceway $<$ PBR & Better in PBR \\
\hline Biomass productivity & Raceway $<$ PBR & $3-5$ times more in PBR \\
\hline Capex and Opex & Raceway $<<$ PBR & 3-10 times cheaper in Raceways
\end{tabular}

\section{Challenges and Limitations}

\subsection{Algal-Bacterial Co-Cultivation}

Some of the challenges and limitations encountered in the algal-bacterial wastewater treatment methods are: (i) expression of antagonistic effect amongst the microbes for, e.g., high $\mathrm{pH}$ and $\mathrm{O}_{2}$ levels produced due to algal growth or secondary metabolites produced by algae having antibacterial activity could negatively impact bacterial population, and on the other hand, the pathogenic bacterial effect could weaken the algal cell wall leading to lysis of the cell and ultimately death; (ii) microbial sensitivity to the changing environmental and operational conditions adversely affects their growth and performance; (iii) inhibition of nitrification process, excessive filamentous bacterial population leads to bulking, and foaming; (iv) difficulty in handling and proper disposal of sludge generated in bulk quantity; and (v) inefficient microalgal harvesting systems [143].

\subsection{Efficient $\mathrm{CO}_{2}$ Sparging and Mixing Systems}

Very slow diffusion of $\mathrm{CO}_{2}$ in aqueous solution than in air is one of the key limitations that affect its fixation by microalgae [154]. Therefore, despite having an atmospheric concentration as high as $400 \mathrm{ppm}$, due to poor diffusion of $\mathrm{CO}_{2}$ in water, direct atmospheric $\mathrm{CO}_{2}$ capture is still at infancy stage and requires substantial research. In the conventional system, $\mathrm{CO}_{2}$ (pure form or flue gas) or air is injected into the algal cultivation pond with the help of sparger fitted at the bottom. However, it has limited transfer efficiency with respect to culture temperature, column height, water depth, and bubble size [155]. Studies report that sparging of larger $\mathrm{CO}_{2}$ bubbles to raceways has a typical mass transfer efficiency of less than $50 \%$, resulting in limited $\mathrm{CO}_{2}$ absorption and outgassing, losing $\mathrm{CO}_{2}$ to the atmosphere [156]. Some of the technological developments to overcome this include (i) the use of an external gas diffuser like hollow fiber membranes and porous materials fabricated 
to regulate gas flow rates [110,157], (ii) microbubbles (with reduced size $<100 \mu \mathrm{m}$ ) to improve mass transfer efficiency by larger surface to volume ratio and slower rise velocity in the aqueous culture solution, thus leading to better dissolution of $\mathrm{CO}_{2}$ in the medium facilitating $\mathrm{CO}_{2}$ fixation [110], and (iii) use of $\mathrm{CO}_{2}$ containing solvents, passed through non-porous membranes to minimize $\mathrm{CO}_{2}$ loss and transportation energy and avoid gas compression. Despite the above, high capital cost associated with the membrane still pose limitation [158]. Furthermore, additional costs for energy requirements and maintenance of the system such as mitigation of plug biofouling, complex control systems, especially in large algal farms, etc. are the other constraints with these systems [156].

\subsection{Heavy Metals and Other Toxicants in the Effluents}

Heavy metals such as $\mathrm{As}, \mathrm{Cd}, \mathrm{Cr}, \mathrm{Hg}, \mathrm{Pb}, \mathrm{Zn}$, etc. and other toxic chemicals such as biocides, hydrocarbons, surfactants, etc. are present in different forms and quantities in the effluents from mines, ores and metal processing industries, textiles, leather, tanneries, electroplating, etc. [159]. The algal growth suffers in industrial wastewaters due to a lack of consistent quality of effluent, i.e., either a deficiency or abundance of particular chemical(s) that could be detrimental to algal survival. This is often experienced in industrial wastewaters with low $\mathrm{N}$ and $\mathrm{P}$ compounds or with high inorganic chemicals, heavy metals, etc. Therefore, studies are required to identify potential algal strains that can bioaccumulate heavy metals and customize their growth according to the qualities of industrial wastewaters. Additionally, acidification, ammonium toxicity, nutrient imbalance, and turbidity are common problems encountered with the treatment of liquid digestate [109].

\subsection{Need for Efficient Algae Harvesting Techniques}

Harvesting is an important part of algae-based wastewater treatment [160]. Though it is generally considered that the biomass recovery takes $20-30 \%$ of the overall algal production cost, there are simple methods that are to be tried for separation of biomass [161]. Some of the methods available are sedimentation, flocculation, centrifugation filtration, sonication, precipitation, and flotation. Belt-filtering, filter press, floatation with float collection, micro-straining, and sedimentation are studied for biofuel extraction [162]. Some methods use different combinations of harvesting methods to increase the biomass separation. In some cases, dewatering is followed to remove water content from cells to obtain dry biomass [163]. However, every technique has its own advantages and disadvantages, such as time, economy, damage to the biomass, ease of operation, continuous operations, occupation of space, energy, chemicals, fouling, clogging of machines, etc. [51,161,164,165].

The development of an efficient as well as cost-effective microalgal harvesting system is the most priority requirement in microalgae cultivation technology. Harvesting micron sized, single-celled microalgae from the cultivation systems operating with large volumes is not only difficult but also expensive. The lack of such efficient harvesting system is the major limiting factor for adoption of algal-based wastewater treatment by industries [166]. In the current practice, harvesting is simplified by flocculation step, followed by filtration using membrane or ultrafiltration or centrifugal sedimentation or gravity settling.

\subsection{Post-Harvest Preservation and Storage}

Another important area to be addressed is the processing of the algal biomass after harvest. The biomass especially generated in wastewater needs proper and immediate valorization such as bioenergy or biomanure applications, without which it can pose threat to the environment again [160]. Storage in wet form consumes a lot of energy, and drying is also another expensive step. Freshly harvested algal slurry or in paste form is not a stable product, and all components will degrade, generally starting with high-value compounds such as lipids and specialty products such as vitamins. Prevention of spoilage requires the inhibition of unwanted enzymes, organisms, and reactive species. Although post-harvest preservation and storage is a very critical step in algal biotechnology, little research has been conducted on the spoilage of algal products after harvest [167]. 
Drying the harvested wet microalgal slurry containing an average of $80 \%$ moisture to obtain storable dry biomass with $5-10 \%$ moisture is challenging. Eliminating moisture from slurry is a laborious and time-consuming process and not as easy as dehydration of agricultural crops or residues. The long drying time significantly adds to costs. For algal-based fuel production, though drying is a suitable method, it is not yet commercially practical due to its associated challenges [168]. While many methods are available, viz., spray-drying, drum-drying, and sun-drying, Richmond [130] has shown that filtration followed by sun drying is the economically feasible option. However, at a large scale, this method is yet to be extensively explored.

\section{Conclusions}

The treatment of wastewater by employing the algal-bacterial consortia has great potential to become a major alternative to other aeration-based treatment technologies including activated sludge treatment, mainly due to their efficiency, requirement of less energy, and production of biomass, which could be valorized. Removal of organic and inorganic nutrient loads in municipal and industrial waste waters by various means of treatment before discharging into environment is essential to avoid any adverse impact on both human and aquatic lives. Microalgae are potential and eco-friendly candidates due to their capability to both utilize the nutrients available in waste waters as well as act as the largest carbon sink. In addition, they also produce good quantities of biomass that serve as a source for extracting many useful compounds. The futuristic sustainable solution from social, environmental, and economic perspectives would be to integrate the processes of $\mathrm{CO}_{2}$ sequestration and wastewater treatment by algal-bacterial consortia. However, this will largely depend on conceiving, establishing, and demonstrating an integrated technology taking all prevailing parameters specific to an industry into consideration to develop a customized viable solution.

Funding: This research received no external funding.

Institutional Review Board Statement: Not applicable.

Informed Consent Statement: Not applicable.

Data Availability Statement: Not applicable.

Acknowledgments: The authors acknowledge Shri A.M.M. Murugappa Chettiar Research Centre (MCRC), Chennai for the facilities and support and the internal Technical Committee for their valuable inputs to publish this review article.

Conflicts of Interest: The authors declare no conflict of interest.

\section{References}

1. NOAA Report. Available online: https://www.giss.nasa.gov/research/news/20170118/ (accessed on 2 October 2020).

2. Hossain, M.M.; de Lasa, H.I. Reactivity and stability of $\mathrm{Co}-\mathrm{Ni} / \mathrm{Al}_{2} \mathrm{O}_{3}$ oxygen carrier in a multicycle CLC. AIChE J. 2007, 53, 1817-1829. [CrossRef]

3. Sayer, R. Microalgae: The potential for carbon capture. Bioscience 2010, 60, 722-727. [CrossRef]

4. IEA. Global Energy \& $\mathrm{CO}_{2}$ Status Report 2019; IEA: Paris, France, 2019. Available online: https://www.iea.org/reports/globalenergy-co2-status-report-2019 (accessed on 5 November 2020).

5. United Nations Climate Change Annual Report. United Nations Framework Convention on Climate Change (UNFCCC). 2019, p. 62. Available online: https://unfccc.int/sites/default/files/resource/unfccc_annual_report_2019.pdf (accessed on 20 November 2020).

6. Wang, B.; Li, Y.; Wu, N.; Lan, C.Q. $\mathrm{CO}_{2}$ bio-mitigation using microalgae. Appl. Microbiol. Biotechnol. 2008, 79, 707-718. [CrossRef] [PubMed]

7. Khairul, S.N.K. Synthesis and Modification of Micro and Mesoporous Materials as $\mathrm{CO}_{2}$ Adsorbents. 2009. Available online: http:/ / eprints.utm.my/id/eprint/9749/1/78207.pdf (accessed on 6 October 2019).

8. IPCC. Climate change 2001: Impacts, Adaptation and Vulnerability, Contribution of Working Group II to the Third Assessment Report of the Intergovernmental Panel on Climate Change; McCarthy, J.J., Canziani, O.F., Leary, N.A., Dokken, D.J., White, K.S., Eds.; Cambridge University Press: Cambridge, UK; New York, NY, USA, 2001; p. 1032. 
9. Bhola, V.; Swalaha, F.; Ranjith Kumar, R.; Singh, M.; Bux, F. Overview of the potential of microalgae for $\mathrm{CO}_{2}$ sequestration. Intl. J. Environ. Sci. Technol. 2014, 11. [CrossRef]

10. Sydney, E.B.; Sturm, W.S.; de Carvalho, J.C.; Thomaz-Soccol, V.; Larroche, C.; Pandey, A.; Soccol, C.R. Potential carbon dioxide fixation by industrially important microalgae. Bioresour. Technol. 2010, 101, 5892-5896. [CrossRef]

11. Weerahandi, N.; Ngo, V.; Fagan, J.M. Alternative Fuels for Vehicle. An overview of various approaches for reducing greenhouse gas emissions and ending oil dependence. 2012; 1-13.

12. Atomi, H. Microbial enzymes involved in carbon dioxide fixation. J. Biosci. Bioeng. 2002, 94, 497-505. [CrossRef]

13. Parry, M.A.; Andralojc, P.J.; Mitchell, R.A.; Madgwick, P.J.; Keys, A.J. Manipulation of Rubisco: The amount, activity, function and regulation. J. Exp. Bot. 2003, 54, 1321-1333. [CrossRef]

14. Cheah, W.Y.; Show, P.L.; Chang, J.S.; Ling, T.C.; Juan, J.C. Biosequestration of atmospheric $\mathrm{CO}_{2}$ and flue gas containing $\mathrm{CO}_{2}$ by microalgae. Bioresour. Technol. 2015, 184, 190-201. [CrossRef]

15. Miura, Y.; Yamada, W.; Hirata, K.; Miyamoto, K.; Kiyohara, M. Stimulation of hydrogen production in algal cells grown under high $\mathrm{CO}_{2}$ concentration and low temperature. Appl. Biochem. Biotechnol. 1993, 39/40, 753-761. [CrossRef]

16. Hanagata, N.; Takeuchi, T.; Fukuju, Y.; Barnes, D.J.; Karube, I. Tolerance of microalgae to high $\mathrm{CO}_{2}$ and high temperature. Phytochem. 1992, 31, 3345-3348. [CrossRef]

17. Fulke, A.B.; Chambhare, K.; Giripunje, M.D.; Sangolkar, L.; Krishnamurthi, K. Potential of wastewater grown algae for biodiesel production and $\mathrm{CO}_{2}$ sequestration. Afr. J. Biotechnol. 2013, 12, 2939-2948.

18. Fulke, A.B.; Mudliar, S.N.; Yadav, R.; Shekh, A.; Srinivasan, N.; Ramanan, R.; Krishnamurthi, K.; Saravana Devi, S.; Chakrabarti, T. Bio-mitigation of $\mathrm{CO}_{2}$, calcite formation and simultaneous biodiesel precursors production using Chlorella sp. Bioresour. Technol. 2010, 101, 8473-8476. [CrossRef]

19. Jin, H.F.; Lim, B.R.; Lee, K. Influence of nitrate feeding on carbon dioxide fixation by microalgae. J. Environ. Sci. Health A Tox. Hazard. Subs. Environ. Eng. 2006, 41, 2813-2824. [CrossRef] [PubMed]

20. Ryu, H.J.; Oh, K.K.; Kim, Y.S. Optimization of the influential factors for the improvement of $\mathrm{CO}_{2}$ utilization efficiency and $\mathrm{CO}_{2}$ mass transfer rate. J. Indus. Engg. Chem. 2009, 15, 471-475. [CrossRef]

21. Zhao, B.; Zhang, Y.; Xiong, K.; Zhang, Z.; Hao, X. Effect of cultivation mode on microalgal growth and $\mathrm{CO}_{2}$ fixation. Chem. Eng. Res. Design 2011, 89, 1758-1762. [CrossRef]

22. de Morais, M.G.; Costa, J.A.V. Carbon-dioxide fixation by Chlorella kessleri, C. vulgaris, Scenedesmus obliquus and Spirulina sp. cultivated in flasks and vertical tubular photobioreactors. Biotechnol. Lett. 2007, 29, 1349-1352. [CrossRef] [PubMed]

23. Chiu, S.; Kao, C.; Shen, C.; Kuan, T.; Ong, S.; Lin, S. Reduction of $\mathrm{CO}_{2}$ by a high-density culture of Chlorella sp. in a semicontinous photobioreactor. Bioresour. Technol. 2008, 99, 3389-3396. [CrossRef]

24. Tang, D.; Han, W.; Miao, X.; Zhong, J. $\mathrm{CO}_{2}$ biofixation and fatty acid composition of Scenedesmus obliquus and Chlorella pyrenoidosa in response to different $\mathrm{CO}_{2}$ levels. Bioresour. Technol. 2011, 102, 3071-3076. [CrossRef]

25. Yeh, K.L.; Chang, J.S. Nitrogen starvation strategies and photobioreactor design for enhancing lipid content and lipid production of a newly isolated microalga Chlorella vulgaris ESP-31: Implications for biofuels. Biotechnol. J. 2011, 6, 1358-1366. [CrossRef] [PubMed]

26. Kurano, N.; Ikemoto, H.; Miyashita, H.; Hasegawa, T.; Hata, H.; Miyachi, S. Fixation and utilization of carbon-dioxide by microalgal photosynthesis. Energy Convers. Manag. 1995, 36, 689-692. [CrossRef]

27. Kodama, M.; Ikemoto, H.; Miyachi, S. A new species of highly $\mathrm{CO}_{2}$-tolreant fast-growing marine microalga suitable for highdensity culture. J. Marine Biotechnol. 1993, 1, 21-25.

28. Seckbach, J.; Gross, H.; Nathan, M.B. Growth and photosynthesis of Cyanidium caldarium cultured under pure $\mathrm{CO}_{2}$. Isr. J. Bot. 1971, 20, 84-90.

29. Kishimoto, M.; Okakura, T.; Nagashima, H.; Minowa, T.; Yokoyama, S.Y. $\mathrm{CO}_{2}$ fixation and oil production using microalgae. J. Ferment. Bioeng. 1994, 78, 479-482. [CrossRef]

30. Francisco, E.C.; Neves, D.B.; Jacob-Lopes, E.; Franco, T.T. Algae as feedstock for biofuel production: Carbon dioxide sequestration, lipid production and biofuel quality. J. Chem. Technol. Biotechnol. 2010, 85, 395-403. [CrossRef]

31. Nakano, Y.; Miyatake, K.; Okuno, H.; Hamazaki, K.; Takenaka, S.; Honami, N.; Kiyota, M.; Aiga, I.; Kondo, J. Growth of photosynthetic algae Euglena in high $\mathrm{CO}_{2}$ conditions and its photosynthetic characteristics. Acta Hort. 1996, 440, 49-54. [CrossRef]

32. Huntley, M.; Redalje, D. $\mathrm{CO}_{2}$ mitigation and renewable oil from photosynthetic microbes: A new appraisal. Mitig. Adapt. Strat. Glob. Chang. 2007, 12, 573-608. [CrossRef]

33. Yoshihara, K.; Nagase, H.; Eguchi, K.; Hirata, K.; Miyamoto, K. Biological elimination of nitric oxide and carbon dioxide from flue gas by marine microalga NOA-113 cultivation in a long tubular photobioreactor. J. Ferment. Bioeng. 1996, 82, 351-354. [CrossRef]

34. Ho, S.H.; Chen, C.Y.; Yeh, K.L.; Chen, W.M.; Lin, C.Y. Characterization of photosynthetic carbon-dioxide fixation ability of indigenous Scenedesmus obliquus isolates. Biochem. Eng. J. 2010, 53, 57-62. [CrossRef]

35. Ho, S.H.; Li, P.J.; Liu, C.C.; Chang, J.S. Bioprocess development on microalgae-based $\mathrm{CO}_{2}$ fixation and bioethanol production using Scenedesmus obliquus CNW-N. Bioresour. Technol. 2013, 145, 142-149. [CrossRef] [PubMed]

36. Miyairi, S. $\mathrm{CO}_{2}$ assimilation in a thermophilic cyanobacterium. Energy Convers. Manag. 1995, 36, 763-766. [CrossRef]

37. Sivakumar, M.; Ranjithkumar, R.; Shashirekha, V.; Seshadri, S. Influence of carbon-dioxide on the growth of Spirulina sp. (MCRC-A0003) isolated from Muttukadu backwaters, South India. World J. Microbiol. Biotechnol. 2014, 30, 2775-2781. [CrossRef] [PubMed] 
38. Kumar, A.; Yuan, X.; Sahu, A.K.; Erga, S.J.; Langenhove, V. A hollow fiber membrane photo-bioreactor for $\mathrm{CO}_{2}$ sequestration from combustion gas coupled with wastewater treatment: A process engineering approach. J. Chem. Technol. Biotechnol. 2010, 85, 387-394. [CrossRef]

39. Matsumoto, H.; Shioji, N.; Hamasaki, A.; Ikuta, Y.; Fukuda, Y.; Sato, M.; Endo, N.; Tsukamoto, T. Carbon dioxide fixation by microalgae photosynthesis using actual flue gas discharged from a boiler. Appl. Biochem. Biotechnol. 1995, 51/52, 681-692. [CrossRef]

40. Nagase, H.; Eguchi, K.; Yoshihara, K.; Hirata, K.; Miyamoto, K. Improvement of microalgal $\mathrm{NO}_{\mathrm{x}}$ removal in bubble column and airlift reactors. J. Ferment. Bioeng. 1998, 86, 421-423. [CrossRef]

41. Ramanan, R.; Kannan, K.; Deshkar, A.; Yadav, R.; Chakrabarti, T. Enhanced algal $\mathrm{CO}_{2}$ sequestration through calcite deposition by Chlorella sp. and Spirulina platensis in a mini-raceway pond. Bioresour. Technol. 2010, 101, 2616-2622. [CrossRef]

42. Ramirez-Perez, J.C.; Janes, H.W. Carbon-dioxide sequestration by Spirulina platensis in photo-bioreactors. Habitation 2009, 12, 65-77. [CrossRef]

43. Jones, C.S.; Mayfield, S.P. Algae biofuels: Versatility for the future of bioenergy. Curr. Opin. Biotechnol. 2012, $23,346-351$. [CrossRef] [PubMed]

44. Ferro, L. Wastewater Treatment and Biomass Generation by Nordic Microalgae: Growth in Subarctic Climate and Microbial Interactions (PhD Dissertation, Umeå University). 2019. Available online: http://urn.kb.se/resolve?urn=urn:nbn:se:umu: diva-156470 (accessed on 27 July 2021).

45. Larsson, M.; Lindblom, J. Algal flue gas sequestration and wastewater treatment: An industrial experiment. Master's Thesis, KTH Industrial Engineering and Management Machine Design, Industrial Ecology, Royal Institute of Technology, Stockholm, Sweden, 2011; p. 75.

46. Lizzul, A.M.; Hellier, P.; Purton, S.; Baganz, F.; Ladommatos, N.; Campos, L. Combined remediation and lipid production using Chlorella sorokiniana grown on wastewater and exhaust gases. Bioresour. Technol. 2014, 151, 12-18. [CrossRef]

47. Oswald, W.J.; Golueke, C. Biological transformation of solar energy. Adv. Appl. Microbiol. 1960, 2, 223-262. [PubMed]

48. Tam, N.F.Y.; Wong, Y.S. Wastewater Treatment with Microorganisms; The Commercial Press (H.K.) Ltd.: Hong Kong, China, 1995.

49. McGinn, P.J.; Dickinson, K.E.; Bhatti, S.; Frigon, J.C.; Guiot, S.R.; O'Leary, S.J.B. Integration of microalgae cultivation with industrial waste remediation for biofuel and bioenergy production: Opportunities and limitations. Photosynth Res. 2011, 109, 231-247. [CrossRef]

50. Posadas, E.; Alcántara, C.; García-Encina, P.A.; Gouveia, L.; Guieysse, B.; Norvill, Z.; Acién, F.G.; Markou, G.; Congestri, R.; Koreiviene, J.; et al. Microalgae cultivation in wastewater. Chapter 3. In Microalgae-Based Biofuels and Bioproducts; GonzalezFernandez, C., Muñoz, R., Eds.; Woodhead Publishing Series in Energy; Woodhead Publishing: Chicago, IL, USA, 2017; ISBN 9780081010235. [CrossRef]

51. Muñoz, R.; Guieysse, B. Algal-bacterial processes for the treatment of hazardous contaminants: A review. Water Res. 2006, 40, 2799-2815. [CrossRef]

52. Khiewwijit, R.; Temmink, H.; Rijnaarts, H. Energy and nutrient recovery for municipal wastewater treatment: How to design a feasible plant layout? Environ. Model. Softw. 2015, 68, 156-165. [CrossRef]

53. Gu, Y.; Li, Y.; Li, X.; Luo, P.; Wang, H.; Wang, X.; Wu, J.; Li, F. Energy self-sufficient wastewater treatment plants: Feasibilities and challenges. Energy Procedia. 2017, 105, 3741-3751. [CrossRef]

54. Mallick, N. Biotechnological potential of immobilized algae for wastewater N, P and metal removal: A review. BioMetals 2002, 15, 377-390. [CrossRef]

55. Nagarajan, D.; Lee, D.J.; Chang, J.S. Integration of anaerobic digestion and microalgal cultivation for digestate bioremediation and biogas upgrading. Bioresour. Technol. 2019, 290, 121804. [CrossRef] [PubMed]

56. Pittman, J.K.; Dean, A.P.; Osundeko, O. The potential of sustainable algal biofuel production using wastewater resources. Bioresour. Technol. 2011, 102, 17-25. [CrossRef]

57. Ansari, A.A.; Khoja, A.H.; Nawar, A.; Qayyum, M.; Ali, E. Wastewater treatment by local microalgae strains for $\mathrm{CO}_{2}$ sequestration and biofuel production. Appl. Water Sci. 2017, 7, 4151-4158. [CrossRef]

58. Koutra, E.; Grammatikopoulos, G.; Kornaros, M. Microalgal posttreatment of anaerobically digested agro-industrial wastes for nutrient removal and lipids production. Bioresour. Technol. 2017, 224, 473-480. [CrossRef] [PubMed]

59. Álvarez, X.; Otero, A. Nutrient removal from the centrate of anaerobic digestion of high ammonium industrial wastewater by a semicontinuous culture of Arthrospira sp. and Nostoc sp. PCC 7413. J. Appl. Phycol. 2020. [CrossRef]

60. Chuka-ogwude, D.; Ogbonna, J.; Borowitzka, M.A.; Moheimani, N.R. Screening, acclimation and ammonia tolerance of microalgae grown in food waste digestate. J. Appl. Phycol. 2020, 32, 3775-3785. [CrossRef]

61. Krzemińska, I.; Oleszek, M.; Wiącek, D. Liquid anaerobic digestate as a source of nutrients for lipid and fatty acid accumulation by Auxenochlorella protothecoides. Molecules 2019, 24, 3582. [CrossRef] [PubMed]

62. Kisielewska, M.; Dębowski, M.; Zieliński, M.; Kazimierowicz, J.; Quattrocelli, P.; Bordiean, A. Effects of liquid digestate treatment on sustainable microalgae biomass production. Bioenergy Res. 2021, 1-14. [CrossRef]

63. Wang, B.; Lan, C.Q. Biomass production and nitrogen and phosphorus removal by the green alga Neochloris oleoabundans in simulated wastewater and secondary municipal wastewater effluent. Bioresour. Technol. 2011, 102, 5639-5644. [CrossRef] [PubMed] 
64. Sepúlveda, C.; Acién, F.G.; Gómez, C.; Jiménez-Ruíz, N.; Riquelme, C.; Molina-Grima, E. Utilization of centrate for the production of the marine microalgae Nannochloropsis gaditana. Algal. Res. 2015, 9, 107-116. [CrossRef]

65. Garbisu, C.; Hall, D.O.; Serra, J.L. Removal of phosphate from water by foam-immobilized Phormidium laminosum in batch and continuous-flow bioreactors. J. Chem. Technol. Biotechnol. 1993, 57, 181-189. [CrossRef]

66. Shashirekha, V.; Sivakumar, M.; Seshadri, S. Effective C-N-P ratio for growth and nutrient removal efficiency of Scenedesmus obliquus in sugar mill effluent. Energy Ecol. Environ. 2016, 1, 283-295. [CrossRef]

67. Shashirekha, V.; Sudhakar, M.P. Microalgae: Potential agents for $\mathrm{CO}_{2}$ mitigation and bioremediation of wastewaters. Chapter 8 . In New and Future Developments in Microbial Biotechnology and Bioengineering: Microbes in Soil, Crop and Environmental Sustainability; Singh, J.S., Singh, D.P., Eds.; Elsevier: Amsterdam, The Netherlands, 2019; pp. 129-148. [CrossRef]

68. Wijffels, R.H.; Barbosa, M.J. An outlook on microalgal biofuels. Science 2010, 329, 796-799. [CrossRef] [PubMed]

69. Sudhakar, M.P.; Shashirekha, V. Algae as a sustainable and renewable bioresource for bio-fuel production. Chapter 6. In New and Future Developments in Microbial Biotechnology and Bioengineering: Microbial Biotechnology in Agro-Environmental Sustainability; Singh, J.S., Singh, D.P., Eds.; Elsevier: Amsterdam, The Netherland, 2019; pp. 77-84, ISBN 9780444641915. [CrossRef]

70. Park, J.B.K.; Craggs, R.J.; Shilton, A.N. Wastewater treatment high rate algal ponds for biofuel production. Bioresour. Technol. 2011, 102, 34-42. [CrossRef] [PubMed]

71. González-Fernández, C.; Sialve, B.; Bernet, N.; Steyer, J.P. Impact of microalgae characteristics on their conversion to biofuel. Part II: Focus on biomethane production. Biofuel Bioprod. Bioref. 2012, 6, 205-218. [CrossRef]

72. Wilkie, A.C.; Edmundson, S.J.; Duncan, J.G. Indigenous algae for local bioresource production: Phycoprospecting. Energy Sustain. Dev. 2011, 15, 365-371. [CrossRef]

73. Eric, F.; Christophe, V.; Christophe, L.; Emilie, L.F.; Claire, C.; Bruno, M.; Jean-Philippe, S.; Bruno, S. Coupling algal biomass production and anaerobic digestion: Production assessment of some native temperate and tropical microalgae. Biomass Bioenergy 2014, 70, 564-569.

74. Razzak, S.A.; Hossain, M.M.; Lucky, R.A.; Bassi, A.S.; de Lasa, H. Integrated $\mathrm{CO}_{2}$ capture, wastewater treatment and biofuel production by microalgae culturing-A review. Renew. Sustain. Energy Rev. 2013, 27, 622-653. [CrossRef]

75. Cardozo, K.H.M.; Guaratini, T.; Barros, M.P.; Vanessa, R.F.; Tonon, A.P.; Lopes, N.P.; Campos, S.; Torres, M.A.; Souza, A.O.; Colepicolo, P.; et al. Metabolites from algae with economical impact. Comp. Biochem. Physiol. Toxicol. Pharmacol. 2007, 146, 60-78. [CrossRef] [PubMed]

76. Yafei, S. Carbon dioxide bio-fixation and wastewater treatment via algae photochemical synthesis for biofuels production. RSC Adv. 2014, 92, 49672-49722.

77. Gupta, P.L.; Lee, S.M.; Choi, H.J. A mini review: Photobioreactors for large scale algal cultivation. World J. Microbiol. Biotechnol. 2015, 31, 1409-1417. [CrossRef] [PubMed]

78. Maoka, T. Carotenoids as natural functional pigments. J. Nat. Med. 2020, 74, 1-16. [CrossRef]

79. Borowitzka, M.A. Limits to growth. In Wastewater Treatment with Algae; Wong, Y.S., Tam, N.F.Y., Eds.; Springer: Berlin/Heidelberg, Germany, 1998; pp. 203-226.

80. Saad, M.G.; Dosoky, N.S.; Zoromba, M.S.; Shafik, H.M. Algal Biofuels: Current Status and Key Challenges. Energies 2019, 12, 1920. [CrossRef]

81. Bhatnagar, A.; Chinnasamy, S.; Singh, M.; Das, K.C. Renewable biomass production by mixotrophic algae in the presence of various carbon sources and wastewaters. Appl. Energy 2011, 88, 3425-3431. [CrossRef]

82. Márquez-Rocha, F.J. Reassessment of the bioenergetic yield of Arthrospira platensis using continuous culture. World J. Microbiol. Biotechnol. 1999, 15, 235-238. [CrossRef]

83. Ashraf, A.; Ramamurthy, R.; Sayavedra, S.M.; Bhatt, P.; Gangola, S.; Noor, T.; Desmarais, M.; Rabbani, A.; Rene., E.R. Integrating photobioreactor with conventional activated sludge treatment for nitrogen removal from sidestream digestate: Current challenges and opportunities. J. Environ. Chem. Eng. 2021, 3, 106171. [CrossRef]

84. Qin, L.; Wang, B.; Feng, P.; Cao, Y.; Wang, Z.; Zhu, S. Treatment and resource utilization of dairy liquid digestate by nitrification of biological aerated filter coupled with assimilation of Chlorella pyrenoidosa. Environ. Sci. Pollut. Res. 2021. [CrossRef] [PubMed]

85. Martinez, M.E.; Jimenez, J.M.; Yousfi, E.L. Influence of phosphorus concentration and temperature on growth and phosphorus uptake by the microalga Scenedesmus obliquus. Bioresour. Technol. 1999, 67, 233-240. [CrossRef]

86. Weissman, J.C.; Tillett, D.M. Design and Operation of an Outdoor Microalgae Test Facility: Large-Scale System Results. In Aquatic Species Project Report (FY 1989-90); NREL/TP-232-4174; Brown, L.M., Sprague, S., Eds.; National Renewable Energy Laboratory: Golden, CO, USA, 1992; pp. 32-56.

87. Becker, E.W. Microalgae: Biotechnology \& Microbiology; Cambridge University Press: Cambridge, UK, 1994.

88. Dalrymple, O.K.; Halfhide, T.; Udom, I.; Gilles, B.; Wolan, J.; Zhang, Q.; Ergas, S. Wastewater use in algae production for generation of renewable resources: A review and preliminary results. Aquat. Biosyst. 2013, 9, 2. [CrossRef] [PubMed]

89. Ruiz-Marin, A.; Mendoza-Espinosa, L.G.; Stephenson, T. Growth and nutrient removal in free and immobilized green algae in batch and semi-continuous cultures treating real wastewater. Bioresour. Technol. 2010, 101, 58-64. [CrossRef] [PubMed]

90. Bhatnagar, M.; Chinnasamy, S. Chlorella minutissima-A promising fuel alga for cultivation in municipal wastewaters. Appl. Biochem. Biotechnol. 2010, 161, 523-536. [CrossRef] [PubMed]

91. Anand, M.N. Microalgal Bioremediation of Nutrients in Wastewater and Carbon-Dioxide in Flue Gas. Master's Thesis, Environmental Engineering, Missouri University of Science and Technology, Rolla, MO, USA, 2010. 
92. Gao, F.; Li, C.; Yang, Z.H.; Zeng, G.M.; Feng, L.J.; Liu, J.Z.; Liu, M.; Cai, H.W. Continuous microalgae cultivation in aquaculture wastewater by a membrane photobioreactor for biomass production and nutrients removal. Ecol. Eng. 2016, 92, 55-61. [CrossRef]

93. Khatoon, H.; Banerjee, S.; Syahiran, M.S.; Noordin, N.B.M.; Bolong, A.M.A.; Endut, A. Re-use of aquaculture wastewater in cultivating microalgae as live feed for aquaculture organisms. Desalin. Water Treat. 2016, 57, 29295-29302. [CrossRef]

94. Hena, S.; Fatimah, S.; Tabassum, S. Cultivation of algae consortium in a dairy farm wastewater for biodiesel production. Water Resour. Ind. 2015, 10,1-14.

95. Kaushik, R.; Prasanna, R.; Joshi, H.C. Utilization of anaerobically digested distillery effluent for the production of Spirulina platensis (ARM 730). J. Sci. Ind. Res. 2006, 65, 521-525.

96. Chi, Z.; Zheng, Y.; Jiang, A.; Chen, S. Lipid production and culturing oleaginous yeast and algae with food waste and municipal wastewater in an integrated process. Appl. Biochem. Biotechnol. 2011, 165, 442-453. [CrossRef] [PubMed]

97. Zhou, W.; Li, Y.; Min, M.; Hu, B.; Zhang, H.; Ma, X.; Li, L.; Cheng, Y.; Chen, P.; Ruan, R. Growing wastewater-borne microalga Auxenochlorella protothecoides UMN280 on concentrated municipal wastewater for simultaneous nutrient removal and energy feedstock production. Appl. Energy 2012, 98, 433-440. [CrossRef]

98. Putri, E.V.; Din, M.F.M.; Ahmed, Z.; Jamaluddin, H.; Chelliapan, S. Investigation of Microalgae for High Lipid Content Using Palm Oil Mill Effluent (POME) as Carbon Source; IACSIT Press: Singapore, 2011; Volume 12, pp. 85-89.

99. Hadiyanto, H.; Nur, M.M.A. Potential of palm oil mill effluent (POME) as medium growth of Chlorella sp. for bioenergy production. Intl. J. Environ. Bioenergy 2012, 3, 67-74.

100. Saikia, M.K.; Kalita, S.; Sarma, G.C. An experimental investigation on growth stimulation (+) and inhibition (-) of algae (Oscillatoria chlorina and Scenedesmus quadricauda) treated with pulp and paper mill effluents. Int. J. Appl. Biol. Pharm. Technol. 2011, 2, 87-94.

101. Usha, M.T.; Chandra, T.S.; Sarada, R.; Chauhan, V.S. Removal of nutrients and organic pollution load from pulp and paper mill effluent by microalgae in outdoor open pond. Bioresour. Technol. 2016, 214, 856-860. [CrossRef]

102. Singh, M.; Reynolds, D.; Das, K.C. Microalgal system for treatment of effluent from poultry litter anaerobic digestion. Bioresour. Technol. 2011, 102, 10841-10848. [CrossRef]

103. Toyub, M.A.; Miah, M.I.; Habib, M.A.B.; Rahman, M.M. Growth performance and nutritional value of Scenedesmus obliquus cultured in different concentrations of sweetmeat factory waste media. Bangladesh J. Anim. Sci. 2008, 37, 86-93. [CrossRef]

104. Hu, B.; Min, M.; Zhou, W.; Du, Z.; Mohr, M.; Chen, P.; Zhu, J.; Cheng, Y.; Liu, Y.; Ruan, R. Enhanced mixotrophic growth of microalga Chlorella sp. on pretreated swine manure for simultaneous biofuel feedstock production and nutrient removal. Bioresour. Technol. Adv. Biol. Waste Treat. Bioconver. Technol. 2012, 126, 71-79. [CrossRef] [PubMed]

105. Michelon, W.; Da Silva, M.L.B.; Mezzari, M.P.; Pirolli, M.; Prandini, J.M.; Soares, H.M. Effects of nitrogen and phosphorus on biochemical composition of microalgae polyculture harvested from phycoremediation of piggery wastewater digestate. Appl. Biochem. Biotechnol. 2016, 178, 1407-1419. [CrossRef] [PubMed]

106. Hasan, R.; Zhang, B.; Wang, L.J.; Shahbazi, A. Bioremediation of swine wastewater and biofuel potential by using Chlorella vulgaris, Chlamydomonas reinhardtii and Chlamydomonas debaryana. J. Pet. Environ. Biotechnol. 2014, 5, 175. [CrossRef]

107. Kim, B.H.; Kang, Z.; Ramanan, R.; Choi, J.E.; Cho, D.H.; Oh, H.M.; Kim, H.S. Nutrient removal and biofuel production in high rate algal pond (HRAP) using real municipal wastewater. J. Microbiol. Biotechnol. 2014, 24, 1123-1132. [CrossRef] [PubMed]

108. Abinandan, S.; Shashirekha, V.; Vedaraman, N.; Khambhaty, Y.; Seshadri, S.; Sridharan, M.R. Feasibility of microalgal cultivation in soak liquors from leather processing unit. Indian Hydrobiol. 2014, 16, 145-152.

109. Pulgarin, A.; Kapeller, A.G.; Tarik, M.; Egloff, S.; Mariotto, M.; Ludwig, C.; Refardt, D. Cultivation of microalgae at high-density with pretreated liquid digestate as a nitrogen source: Fate of nitrogen and improvements on growth limitations. J. Clean. Prod. 2021, 324, 129238. [CrossRef]

110. de Morais, M.G.; de Morais, E.G.; Duarte, J.H.; Deamici, K.M.; Mitchell, B.G.; Costa, J.A.V. Biological CO 2 mitigation by microalgae: Technological trends, future prospects and challenges. World J. Microbiol. Biotechnol. 2019, 35, 78. [CrossRef]

111. Satyanarayana, K.G.; Mariano, A.B.; Vargas, J.V.C. A review on microalgae, a versatile source for sustainable energy and materials. Int. J. Ener. Res. 2011, 35, 291-311. [CrossRef]

112. Bauer, L.; Ranglová, K.; Masojídek, J.; Drosg, B.; Meixner, K. Digestate as sustainable nutrient source for microalgae—Challenges and Prospects. Appl. Sci. 2021, 11, 1056. [CrossRef]

113. Singh, S.P.; Singh, P. Effect of temperature and light on the growth of algae species: A review. Renew. Sustain. Energy Rev. 2015, 50, 431-444. [CrossRef]

114. Harker, M.; Tsavalos, A.J.; Young, A.J. Use of response surface methodology to optimisecarotenogenesis in the microalga, Haematococcuspluvialis. J. Appl. Phycol. 1995, 7, 399-406. [CrossRef]

115. Shi, T.; Francis, X.; Cunningham, F.X., Jr.; Youmans, M.; Grabowski, B.; Sun, Z.; Gantt, E. Cytochrome f loss in astaxanthinaccumulating cells of Haematococcus pluvialis (Chlorophyceae): Comparison of photosynthetic activity, photosynthetic enzymes and thylakoid membrane polypeptides in red and green cells. J. Phycol. 1995, 51, 897-905.

116. Fan, L.; Vonshak, A.; Boussiba, S. Effect of temperature and irradiance on growth of Haematococcus pluvialis (Chlorophyceae). J. Phycol. 1994, 30, 829-833. [CrossRef]

117. Torzillo, G.; Vonshak, A. Effect of light and temperature on the photosynthetic activity of the cyanobacterium Spirulina platensis. Biomass Bioenerg. 1994, 6, 399. [CrossRef] 
118. Kaplan, A.; Badger, M.R.; Berry, J.A. Photosynthesis and the intracellular inorganic carbon pool in the blue green alga Anabaena variabilis: Response to external $\mathrm{CO}_{2}$ concentration. Planta 1980, 149, 219-226. [CrossRef] [PubMed]

119. Rachlin, J.W.; Grosso, A. The effects of $\mathrm{pH}$ on the growth of Chlorella vulgaris and its interactions with Cadmium toxicity. Arch. Environ. Contam. Toxicol. 1991, 20, 505-508. [CrossRef] [PubMed]

120. Daliry, S.; Hallajisani, A.; Mohammadi, R.J.; Nouri, H.; Golzary, A. Investigation of optimal condition for Chlorella vulgaris microalgae growth. Glob. J. Environ. Sci. Manag. 2017, 3, 217-230.

121. Raeesossadati, M.J.; Ahmadzadeh, H.; McHenry, M.P.; Moheimani, N.R. $\mathrm{CO}_{2}$ bioremediation by microalgae in photobioreactors: Impacts of biomass and $\mathrm{CO}_{2}$ concentrations, light, and temperature. Algal Res. 2014, 6, 78-85. [CrossRef]

122. Patil, L.; Kaliwal, B. Effect of $\mathrm{CO}_{2}$ concentration on growth and biochemical composition of newly isolated indigenous microalga Scenedesmus bajacalifornicus BBKLP-07. Appl. Biochem. Biotechnol. 2017, 182, 335. [CrossRef] [PubMed]

123. Sung, K.D.; Lee, J.S.; Shin, C.S.; Park, S.C. Isolation of a new highly $\mathrm{CO}_{2}$ tolerant fresh water microalga Chlorella sp. KR-1. Korean J. Chem. Eng. 1998, 15, 449-450. [CrossRef]

124. Benemann, J.R. $\mathrm{CO}_{2}$ mitigation with microalgae systems. Energy Convers. Manag. 1997, 38, S475-S479. [CrossRef]

125. Douskova, I.; Doucha, J.; Livansky, K.; Machat, J.; Novak, P.; Umysova, D.; Zachleder, V.; Vitova, M. Simultaneous flue gas bioremediation and reduction of microalgal biomass production costs. Appl. Microbiol. Biotechnol. 2009, 82, 179-185. [CrossRef] [PubMed]

126. Niyogi, K.K. Photoprotection revisited: Genetic and molecular approaches. Ann. Rev. Plant Physiol. Plant Mol. Biol. 1999, 50, 333-359. [CrossRef]

127. Wollman, F.A. State transitions reveal the dynamics and flexibility of the photosynthetic apparatus. EMBO J. 2001, 20, 3623-3630. [CrossRef]

128. Lemeille, S.; Rochaix, J.D. State transitions at the crossroad of thylakoid signalling pathways. Photosynth Res. 2010, 106, 33-46. [CrossRef] [PubMed]

129. Niyogi, K.K.; Truong, T.B. Evolution of flexible non-photochemical quenching mechanisms that regulate light harvesting in oxygenic photosynthesis. Curr. Opin. Plant Biol. 2013, 16, 307-314. [CrossRef]

130. Richmond, A. Handbook of Microalgal Culture: Biotechnology and Applied Phycology, 1st ed.; Blackwell Publishing Ltd.: Hoboken, NJ, USA, 2003

131. Morales-Amaral, M.M.; Gómez-Serrano, C.; Acién, F.G.; Fernández-Sevilla, J.M.; Molina-Grima, E. Production of microalgae using centrate from anaerobic digestion as the nutrient source. Algal Res. 2015, 9, 297-305. [CrossRef]

132. Navarro-López, E.; Ruíz-Nieto, A.; Ferreira, A.; Acién, F.G.; Gouveia, L. Biostimulant potential of Scenedesmus obliquus grown in brewery wastewater. Molecules 2020, 25, 664. [CrossRef] [PubMed]

133. Ranglová, K.; Lakatos, G.E.; Câmara Manoel, J.A.; Grivalský, T.; Suárez Estrella, F.; Acién Fernández, F.G.; Molnár, Z.; Ördög, V.; Masojídek, J. Growth, biostimulant and biopesticide activity of the MACC-1 Chlorella strain cultivated outdoors in inorganic medium and wastewater. Algal Res. 2020, 102136. [CrossRef]

134. Gutzeit, G.; Lorch, D.; Weber, A. Bioflocculent algal-bacterial biomass improves low-cost wastewater treatment. Water Sci. Technol. 2005, 52, 9-18. [CrossRef]

135. Subashchandrabose, S.R.; Ramakrishnan, B.; Megharaj, M. Consortia of cyanobacteria/microalgae and bacteria: Biotechnological potential. Biotechnol. Adv. 2011, 29, 896-907. [CrossRef]

136. Aspatwar, A.; Haapanen, S.; Parkkila, S. An uptake on the metabolic roles of carbonic anhydrases in the model alga Chlamydomonas reindardtii. Metabolites 2018, 8 , 22. [CrossRef]

137. Hoang, C.V.; Chapman, K.D. Biochemical and molecular inhibition of plastidial carbonic anhydrase reduces the incorporation of acetate into lipids in cotton embryos and tobacco cell suspensions and leaves. Plant Physiol. 2002, 128, 1417-1427. [CrossRef]

138. Hopkinson, B.M.; Meile, C.; Shen, C. Quantification of extracellular carbonic anhydrase activity in two marine diatoms and investigation of its role. Plant Physiol. 2013, 162, 1142-1152. [CrossRef]

139. Moroney, J.V.; Ma, Y.; Frey, W.D.; Fusilier, K.A.; Pham, T.T.; Simms, T.A.; DiMario, R.J.; Yang, J.; Mukherjee, B. The carbonic anhydrase isoforms of Chlamydomonas reinhardtii: Intracellular location, expression, and physiological roles. Photosynth. Res. 2011, 109, 133-149. [CrossRef]

140. Higgins, B.T.; Gennity, I.; Fitzgerald, P.S.; Ceballos, S.J.; Fiehn, O.; VanderGheynst, J.S. Algal-bacterial synergy in treatment of winery wastewater. NPJ Clean Water 2016, 1, 1-9. [CrossRef]

141. Mouget, J.L.; Dakhama, A.; Lavoie, M.C.; la Noüe, J. Algal growth enhancement by bacteria: Is consumption of photosynthetic oxygen involved? FEMS Microbiol. Ecol. 1995, 18, 35-43. [CrossRef]

142. Cho, D.H.; Ramanan, R.; Heo, J.; Kang, Z.; Kim, B.H.; Ahn, C.Y. Organic carbon, influent microbial diversity and temperature strongly influence algal diversity and biomass in raceway ponds treating raw municipal wastewater. Bioresour. Technol. 2015, 191, 481-487. [CrossRef]

143. Sahoo, K.; Sahoo, R.K.; Gaur, M.; Subudhi, E. Algal-bacterial system: A novel low-cost biotechnological initiative in wastewater treatment. In The Role of Microalgae in Wastewater Treatment; Sukla, L.B., Subudhi, E., Pradhan, D., Eds.; Springer: Singapore, 2019; pp. 115-127.

144. Ayre, J.M.; Mickan, B.S.; Jenkins, S.N.; Moheimani, N.R. Batch cultivation of microalgae in anaerobic digestate exhibits functional changes in bacterial communities impacting nitrogen removal and wastewater treatment. Algal Res. 2021, 57, 102338. [CrossRef] 
145. van der Ha, D.; Nachtergaele, L.; Kerckhof, F.M.; Rameiyanti, D.; Bossier, P.; Verstraete, W. Conversion of biogas to bioproducts by algae and methane oxidizing bacteria. Environ. Sci. Technol. 2012, 46, 13425-13431. [CrossRef]

146. Avagyan, A. Microalgae production development global prospects and profitable technology wasterwater purification by the use microalgae. Water Wastewater Int. 2008, 24.

147. Abinandan, S.; Subashchandrabose, S.R.; Venkateswarlu, K.; Megharaj, M. Nutrient removal and biomass production: Advances in microalgal biotechnology for wastewater treatment. Critic. Rev. Biotechnol. 2018, 38, 1244-1260. [CrossRef] [PubMed]

148. Subashchandrabose, S.R.; Ramakrishnan, B.; Megharaj, M.; Venkateswarlu, K.; Naidu, R. Mixotrophic cyanobacteria and microalgae as distinctive biological agents for organic pollutant degradation. Environ. Int. 2013, 51, 59-72. [CrossRef] [PubMed]

149. Pedroni, P.; Davison, J.; Beckert, H.; Bergman, P.; Benemann, J. A proposal to establish an international network on biofixation of $\mathrm{CO}_{2}$ and greenhouse gas abatement with microalgae. J. Ener. and Environ. Res. 2001, 1, 136-150.

150. Seshadri, C.V.; Thomas, S. Mass culture of Spirulina using low-cost nutrients. Biotechnol Lett. 1979, 1, 278-291. [CrossRef]

151. Jeeji Bai, N.; Beena, B.N.; Shashirekha, V. Spirulina (Arthrospira): Taxonomy, Biology and Applications; Bishen Singh Mahendra Pal Singh: Dehradun, India, 2018; p. 112. ISBN 978-81-211-0953-6.

152. Tredici, M.R. Mass production of microalgae: Photobioreactors. In Handbook of Microalgal Culture Biotechnology and Appld. Phycol.; Richmond, A., Ed.; Wiley-Blackwell: Oxford, UK, 2004; pp. 273-280.

153. Soni, R.A.; Sudhakar, K.; Rana, R.S. Sustainable biomass production from microalgae for food, feed and biofuels: An integrated approach. Biosci. Biotechnol. Res. Comm. 2016, 9, 729-736.

154. Moroney, J.V.; Ynalvez, R.A. Proposed carbon-dioxide concentrating mechanism in Chlamydomonas reinhardtii. Eukaryotic Cell 2007, 6, 1251-1259.

155. Cheng, J.; Yang, Z.; Huang, Y.; Huang, L.; Hu, L.; Xu, D.; Cen, K. Improving growth rate of microalgae in a $1191 \mathrm{~m} 2$ raceway pond to fix $\mathrm{CO}_{2}$ from flue gas in a coal-fired power plant. Bioresour. Technol. 2015, 190, 235-241. [CrossRef] [PubMed]

156. Workshop Summary Report. Algae Cultivation for Carbon Capture and Utilization. 2017. Available online: https://www.osti. gov / biblio/1413880 (accessed on 28 August 2021).

157. Chai, X.; Zhao, X. Enhanced removal of carbon dioxide and alleviation of dissolved oxygen accumulation in photobioreactor with bubble tank. Biores. Technol. 2012, 116, 360-365. [CrossRef]

158. Zheng, Q.; $\mathrm{Xu}, \mathrm{X}$.; Martin, G.J.O.; Kentish, S.E. Critical review of strategies for $\mathrm{CO}_{2}$ delivery to large-scale microalgae cultures. Chinese J. Chem. Eng. 2018, 26, 2219-2228, ISSN 1004-9541.

159. Breida, M.; Younssi, S.A.; Ouammou, M.; Bouhria, M.; Hafsi, M. Pollution of water sources from agricultural and industrial effluents: Special attention to NO3-, Cr(VI) and Cu(II). In Water Chemistry; Eyvaz, M., Yüksel, E., Eds.; IntechOpen: London, UK, 2019. [CrossRef]

160. Butterfi, B.A.; Jones, J. Harvesting of algae grown in agricultural wastewaters. Trans. Geophys. Union. 1969, 50, 612.

161. Grima, E.M.; Belarbi, E.H.; Fernández, F.A.; Medina, A.R.; Chisti, Y. Recovery of microalgal biomass and metabolites: Process options and economics. Biotechnol. Adv. 2003, 20, 491-515. [CrossRef]

162. Weissman, J.C.; Goebel, R.P. Design and Analysis of Microalgal Open Pond Systems for the Purpose of Producing Fuels: A Subcontract Report, SERI/STR-231-2840, Solar Energy Research Institute: Golden, CO, United States. 1987. Available online: https:/ / www.osti.gov/servlets/purl/ 6546458 (accessed on 28 August 2021).

163. Chen, C.L.; Chang, J.S.; Lee, D.J. Dewatering and drying methods for microalgae. Dry. Technol. 2015, 33, 443-454. [CrossRef]

164. Bosma, R.; van Spronsen, W.A.; Tramper, J.; Wijffels, R.H. Ultrasound, a new separation technique to harvest microalgae. J. Appl. Phycol. 2003, 15, 143-153. [CrossRef]

165. Brennan, L.; Owende, P. Biofuels from microalgae-A review of technologies for production, processing, and extractions of biofuels and co-products. Renew. Sustain. Energy Rev. 2010, 14, 557-577. [CrossRef]

166. de-Bashan, L.E.; Bashan, Y. Immobilized microalgae for removing pollutants: Review of practical aspects. Bioresour. Technol. 2010, 101, 1611-1627. [CrossRef]

167. Nelson, J.A. Postharvest Degradation of Microalgae: Effect of Temperature and Water Activity; Utah State University: Logan, UT, USA, 2015; p. 4458. [CrossRef]

168. Hosseinizand, H.; Sokhansanj, S.; Lim, J. Studying the drying mechanism of microalgae Chlorella vulgaris and the optimum drying temperature to preserve quality characteristics. Drying Technol. 2017, 36, 1049-1060. [CrossRef] 